\title{
The Ilopango caldera complex, El Salvador: Origin and early ignimbrite-forming eruptions of a graben/pull-apart caldera structure
}

\author{
Ivan Suñe-Puchol $^{\mathrm{a}, *}$, Gerardo J. Aguirre-Díaz ${ }^{\mathrm{a}}$, Pablo Dávila-Harris ${ }^{\mathrm{b}}$, Daniel P. Miggins ${ }^{\mathrm{c}}$, Dario Pedrazzi ${ }^{\mathrm{d}}$, \\ Antonio Costa $^{\mathrm{e}}$, Carlos Ortega-Obregón ${ }^{\mathrm{a}}$, Pierre Lacan ${ }^{\mathrm{a}}$, Walter Hernández ${ }^{\mathrm{f}}$, Eduardo Gutiérrez ${ }^{\mathrm{f}}$ \\ a Centro de Geociencias, Universidad Nacional Autónoma de México, Blvd. Juriquilla 3001, Campus UNAM-Juriquilla, Querétaro, 76230, Mexico \\ b División de Geociencias Aplicadas, IPICYT, San Luis Potosi 78216, Mexico \\ c College of Earth, Ocean and Atmospheric Sciences, Oregon State University, 104 CEOAS Administration Building, 101 SW 26th St, Corvallis, OR 97331, USA \\ d ICTJA, CSIC, Group of Volcanology, SIMGEO UB-CSIC, Institute of Earth Sciences Jaume Almera, Lluis Sole i Sabaris s/n, 08028 Barcelona, Spain \\ e Istituto Nazionale di Geofisica e Vulcanologia, INGV-Bologna, Via Donato Creti, 12, 40100 Bologna, Italy \\ ${ }^{\mathrm{f}}$ Gerencia de Geología del Observatorio Ambiental, Ministerio de Medio Ambiente y Recursos Naturales MARN, San Salvador 76230, El Salvador
}

\section{A R T I C L E I N F O}

\section{Article history:}

Received 3 August 2018

Received in revised form 4 December 2018

Accepted 6 December 2018

Available online $\mathrm{xxx}$

Keywords:

Central America Volcanic Arc

Tectono-volcanism

El Salvador Fault Zone

Fissure eruption

Hydromagmatism

\begin{abstract}
A B S T R A C T
The Ilopango caldera is located in the central part of El Salvador, within the right-lateral El Salvador Fault System (ESFZ) and adjacent to the capital city of San Salvador. The caldera has a polygonal shape of $17 \times 13 \mathrm{~km}$ and hosts an intra-caldera lake. Ilopango caldera had multiple collapse eruptions that formed widespread and voluminous silicic ignimbrites. Volcanic activity of the caldera has been controlled by strike-slip faults of the ESFZ. In this work we present the geological characteristics of the first three ignimbrite-forming eruptions of Ilopango caldera, providing an interpretation of the origin and initial stages of the volcanic evolution of this caldera complex. An initial extensional regime of the ESFZ possibly developed a graben at or near the actual Ilopango caldera, where the graben's master faults worked as fissure vents during the first caldera collapse. The Olocuilta Ignimbrite was emplaced at $1.785 \pm 0.01 \mathrm{MaBP}$, with a Dense Rock Equivalent (DRE) volume $>50 \mathrm{~km}^{3}$ (probably $\sim 300 \mathrm{~km}^{3}$ ). The ESFZ stress gradually changed from extensive to transtensive, inducing the second collapse associated with a pull-apart caldera, producing the Colima Ignimbrite at $1.56 \pm 0.01 \mathrm{MaBP}$, with a DRE volume of $>11 \mathrm{~km}^{3}$. The transtensive regime increased along the ESFZ, producing the third collapse in the pull-apart graben caldera apparently affected by the newly formed strike-slip San Vicente Fault. This phase corresponds to the explosive eruption that formed the Apopa Ignimbrite at $\sim 1.34 \mathrm{MaBP}$, with $>9 \mathrm{~km}^{3}$ DRE volume. The latter ignimbrite marks a change in the eruptive style producing hydromagmatic pyroclastic flows followed by a dense ignimbrite with coignimbrite lithic breccias. These features suggest the involvement of water that could come from a paleoIlopango lake within the caldera depression associated with the second caldera collapse at $1.56 \mathrm{MaBP}$. Ilopango is thus a multistage caldera system associated with the largest explosive events registered in El Salvador so far.
\end{abstract}

\section{Introduction}

Collapse calderas are formed by the subsidence of crustal blocks along bounding faults into a shallow chamber during the fast evacuation of magma (Smith and Bailey, 1968; Druitt and Sparks, 1984; Lipman, 1997, 2000; Gottsmann and Martí, 2008). Caldera eruptions can be explosive or effusive; but, the most catastrophic and voluminous are the explosive ones that can erupt massively large volumes of pyroclastic material within hours to few days (e.g., Newhall and Dzurisin, 1988; Lipman, 1997; Cole et al., 2005; Gottsmann and Martí, 2008; Costa et al., 2014; Costa and Marti, 2016). Silicic collapse calderas are associated with infrequent but catastrophic explosive supereruptions and are considered a major geohazard (e.g., Toba at ca. 74 ka, Francis et al., 1983; Rampino and Self, 1993; Self, 2006).

\footnotetext{
* Corresponding author.

Email address: ivanbatea@gmail.com (I. Suñe-Puchol)
}

In collapse calderas, the subsidence of the chamber roof is produced by syn-collapse faults formed during the collapse phase (e.g., Sparks et al., 1985; Marti et al., 1994; Smith and Braile, 1994; Bacon and Lanphere, 2006; Acocella, 2007). In some cases, collapse calderas used pre-existing tectonic faults as cortical discontinuities to collapse, such as calderas associated with the Sierra Madre Occidental in Mexico (Aguirre-Díaz and Labarthe-Hernández, 2003; Aguirre-Díaz et al., 2008; Gottsmann et al., 2009; Sunye-Puchol et al., 2017), the Cañas Dulces caldera in Costa Rica (Molina et al., 2014), as well as several calderas within the Ethiopian Rift (Acocella et al., 2002; Robertson et al., 2015). The Ilopango caldera (IC) apparently corresponds to this last type, which is known as pull-apart/graben calderas (Aguirre-Díaz, 2008; Aguirre-Díaz et al., 2008) and related to extensional and/or trans-tensional tectonic regimes. Williams and Meyer-Abich (1955) first described IC as a volcano-tectonic depression with several eruptions. Recently, Saxby et al. (2016) interpreted Ilopango as a strike-slip caldera, in the same sense as Aguirre-Díaz and Martí (2015), where the vertical faults of the El Salvador Fault Zone 
(ESFZ) worked as a preferential pathway for magma ascension to the surface (Tikoff and de Saint Blanquat, 1997). Other examples with reports of association between large calderas and pull-apart basins are from Las Sierras-Masaya volcanic complex in Nicaragua (Girard and van Wyk de Vries, 2005; Holohan et al., 2008) and the Toba caldera in Indonesia, within the Great Sumatran Fault Zone (Bellier and Sébrier, 1994). The aim of this work is to study the origin of IC and the first ignimbrite forming eruptions and clarify the relationships between volcanism and the regional transtensive tectonics.

IC is located in the central part of El Salvador, next to the capital city of San Salvador (Fig. 1, index map) and it has a rectangular-rhombohedral shape with $17 \times 13 \mathrm{~km}$. The caldera hosts the Ilopango Lake, which is $231 \mathrm{~m}$ deep, has an area of $70.5 \mathrm{~km}^{2}$ and contains $\sim 12 \mathrm{~km}^{3}$ of water (Sánchez-Esquivel, 2016). The last volcanic event of the caldera is marked by the Islas Quemadas eruption at 1879-1880 (Fig. 2) that formed an intra-lake lava dome (Golombek and Carr, 1978; Richer et al., 2004). The youngest ignimbrite eruption formed by IC has been the historic Tierra Blanca Joven (TBJ) eruption (Williams and Meyer-Abich, 1955; Rose et al., 1999; Hernández, 2004; Kutterolf et al., 2008; Dull et al., 2001; Saxby et al., 2016; Aguirre-Díaz et al., 2017; Pedrazzi et al., 2018), approximately 1500 years ago and that apparently devastated the Mayan civilization in the region (Dull et al., 2010). Prior to TBJ eruption, there were 3 large explosive eruptions during the last $57 \mathrm{ka}$ : TB4, TB3 and TB2 (Rose et al., 1999; Hernández, 2004; Hernández et al., 2010; Kutterolf et al., 2008).

In this work, we show that IC had multiple large-volume ignimbrite eruptions associated with collapse episodes (similar to the Platoro complex in San Juan Mountains; Lipman et al., 1996), and all of them were related to pre-existing regional structure faults associated with the ESFZ. This paper focuses on the ignimbrites of the three earliest volcanic eruptions related to IC, which have not been previously described and interpreted. These are the Olocuilta Ignimbrite (OI), Colima Ignimbrite (CoI), and Apopa Ignimbrite (ApI).
For these three newly mapped ignimbrite sheets, we present their stratigraphic and chemical characteristics as well as a robust geochronological framework, and their link with the coeval tectonics of the region.

\section{Tectonic and geologic setting of Ilopango caldera (IC)}

\subsection{Central America tectonic framework}

IC is the largest active volcano in El Salvador, a Central American country that lies on the Pacific shore of the Caribbean plate (Fig. 1). About $200 \mathrm{~km}$ to the north of San Salvador City is the boundary with the North American plate, represented by the left strike-slip system of Polochic-Motagua-Swan Island Fault (PMSIF), which is the source of the eastward displacement of the Caribbean plate at an average speed of $8 \mathrm{~mm}$ /year (Fig. 1; DeMets, 2001; Guzmán-Speziale et al., 2005; Agostini et al., 2006; Funk et al., 2009). Ilopango is a caldera of the Central American Volcanic Arc (CAVA), which extends from Guatemala to Costa Rica (e.g., Simkin and Siebert, 1994; Carr et al., 2007; Sitemap et al., 2014). The CAVA magmatism is related to the oblique subduction of Cocos under Caribbean plate, developed along the Mesoamerican trench since the early Tertiary until the present day, at an average speed of 73-85 mm/year (Fig. 1; Dixon, 1993; Mann, 2007; DeMets, 2001). Oblique subduction (LaFemina et al., 2009), together with a zipper effect produced at the triple junction in Guatemala (Authemayou et al., 2011), and the decoupled interface initiated by the rollback of the Cocos slab (Alonso-Henar et al., 2015, 2017), might be the causes of the forearc sliver displacement of the El Salvador and Nicaragua to the NW (8-14 mm/year; Fig. 1; Corti et al., 2005; Turner et al., 2007; Alvarado et al., 2011).

The eastward motion of Caribbean plate and the northwestward displacement of the Central American forearc are responsible for the transtensional deformation along the CAVA in a series of en-echelon right-stepping, dextral faults connected by pull-apart basins along

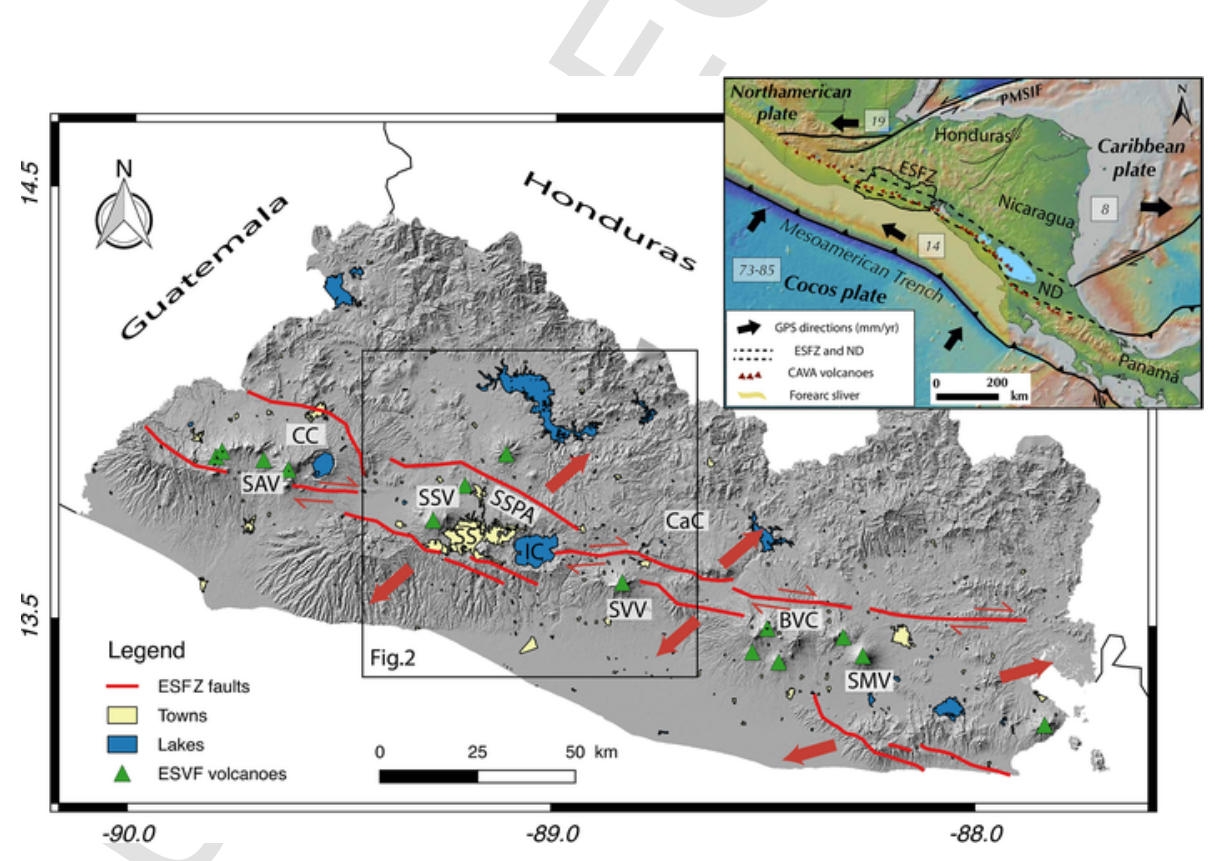

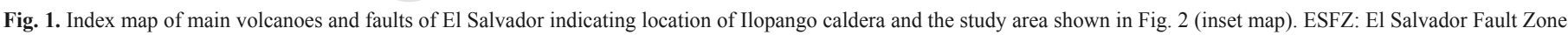

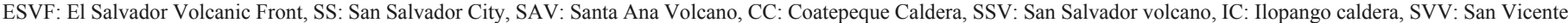

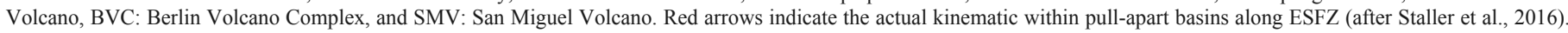

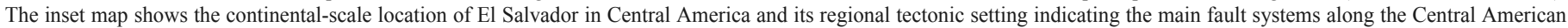
Volcanic Arc - CAVA (after Funk et al., 2009). (For interpretation of the references to colour in this figure legend, the reader is referred to the web version of this article.) 


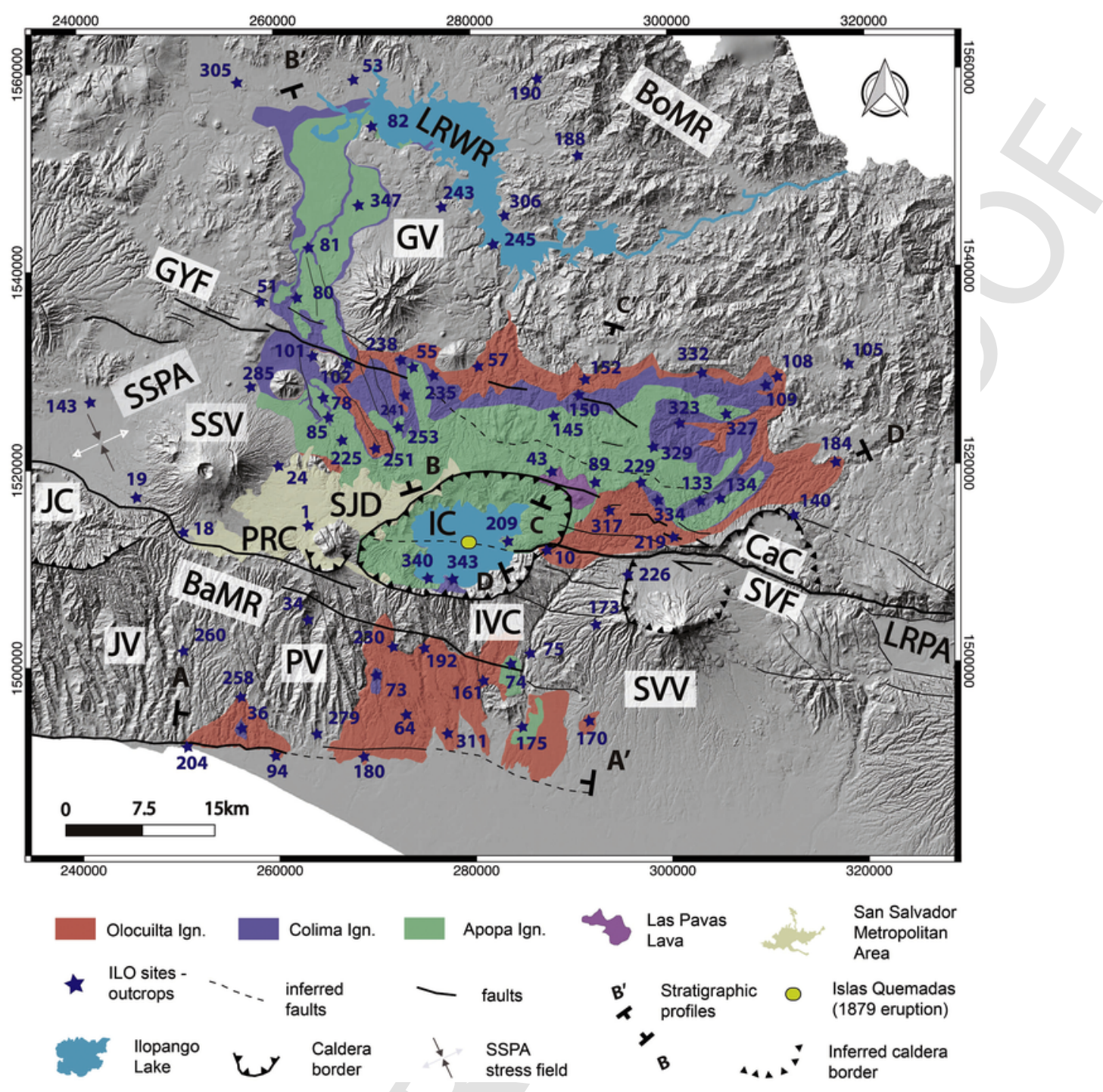

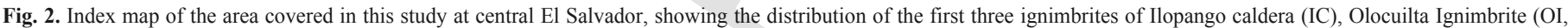

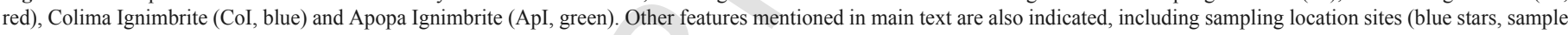

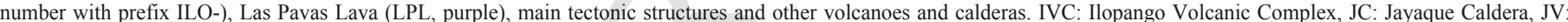

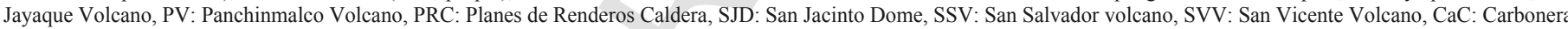

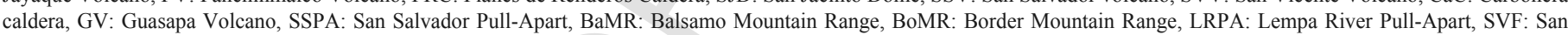

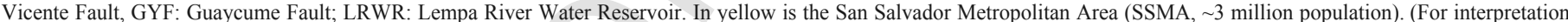
of the references to colour in this figure legend, the reader is referred to the web version of this article.)

fault step-overs (Montero and Dewey, 1982; DeMets, 2001, LaFemina et al., 2009; Corti et al., 2005; Agostini et al., 2006, Turner et al., 2007; Funk et al., 2009; Canora et al., 2014), known as El Salvador Fault Zone (ESFZ; Martínez-Díaz et al., 2004). The ESFZ crosses all of El Salvador with a WNW-ESE trend (Figs. 1 and 2), and results in the opening of the San Salvador Pull-Apart (Garibaldi et al., 2016), where IC is emplaced (Figs. 1 and 2). Carr (1976) mentions a pure extensional regime previous to the actual transtensional regime along the ESFZ, induced by the rollback of the Cocos slab started during the Pliocene (Canora et al., 2014; Alonso-Henar et al., 2015, 2017). Weinberg (1992) proposed a similar geodynamic evolution for the Nicaragua graben, where the present-day deformation is controlled by a right-lateral transtensional regime, localized along the Nicaragua volcanic front and superimposed to a previous rift.

The last fault-slip offset of ESFZ occurred during a Mw 6.7 earthquake on February 13 of 2001, indicating a dominant transcurrent stress field along the San Vicente Fault (Fig. 2; Martínez-Díaz et al., 2004; Alvarenga et al., 2001; Canora et al., 2012). This structure, which is affecting the IC volcanism (Saxby et al., 2016), has totally displaced an older caldera located $12 \mathrm{~km}$ to the east: the Carbonera caldera (Fig. 2; Canora et al., 2014). Since the formation of Carbonera caldera about 2.1 Ma ago (Rotolo and Castorina, 1998), strike-slip tectonics along the San Vicente Fault has been active with dextral sense and an average slip rate of $\sim 5 \pm 0.5 \mathrm{~mm} / \mathrm{yr}$, (Canora et al., 2014). This regional tectonic framework including strike-slip faults, shear zones, pull-apart basins, releasing bends and step-overs, favored the initial pathways for ascension of magma and the emplacement of magmatic centers at shallow levels of the crust (Hutton and Reavy, 1992). 


\subsection{Geologic setting of Ilopango caldera}

El Salvador is predominantly made up of volcanic rocks with ages ranging from the Eocene to the present (Donnelly et al., 1990; Rose et al., 1999). The basement is mainly composed of Jurassic-Cretaceous limestone, represented by the Metapán Formation (Weber et al., 1974), which is sporadically exposed in the NW part of the country. During the Oligocene, volcanism formed the Border Mountain Range at the northernmost part of the country and corresponds to the Morazán and Chalatenango formations. This range marks the geographical border between El Salvador and Honduras (Fig. 2). Since the Miocene, volcanic activity migrated southward and approached the Mesoamerican trench. Volcanism from mid-Miocene to Pliocene formed large basaltic and andesitic stratovolcanoes just south of the actual El Salvador Volcanic Front, such as Panchinmalco Volcano, Jayaque Volcano and the oldest sequence of the Ilopango Volcanic Complex, represented by the Balsamo Formation (Lexa et al., 2011; Fig. 2). The cores of these eroded volcanoes form the Balsamo Mountain Range (Figs. 1 and 2; Williams and Meyer-Abich, 1955). During the Pliocene-Pleistocene, several volcanic edifices collapsed gravitationally apparently associated with the ESFZ structures, forming the calderas of Plan de Renderos and Jayaque both belonging to the Balsamo formation (Lexa et al., 2011), and the Carbonera caldera and early volcanic rocks of the IC that form part of the Cuscatlán Formation (Fig. 2; Weber et al., 1974).

The currently active volcanic belt forms the El Salvador Volcanic Front, which is part of the CAVA (Fig. 1; Carr et al., 2007). Products associated with these volcanic centers from late Pleistocene to Holocene comprise the San Salvador Formation (Weber et al., 1974; Reynolds, 1987; Lexa et al., 2011). The Coatepeque Caldera deposits and late Ilopango Tierras Blancas (TB4, TB3, TB2 and TBJ) are part of this last formation (CEL, 1992; Rose et al., 1999; Hernández, 2004; Hernández et al., 2010; Kutterolf et al., 2008).

\section{Methodology}

\subsection{Field work}

Geologic work was based initially on the El Salvador 1: 500,000 geological map of Weber et al. (1974), as well as on previous maps and stratigraphy reported by other authors (Hernández, 2008; Lexa et al., 2011; Garibaldi et al., 2016). Through this data and several fieldwork campaigns between 2015 and 2017, a new stratigraphic framework and a new geologic map for the Ilopango caldera complex and its surroundings were built. This new map covers around $3000 \mathrm{~km}^{2}$ of the central part of El Salvador, from Border Mountain Range at north, to the Pacific coast at the south, and from the Lempa River Pull-Apart basin at the east, to Jayaque Caldera at the west (Fig. 2).

Prior to, and during fieldwork, outcrops were identified via satellite images to determine the available access. Once identified and reached, exposures were described geologically, measured for stratigraphic sections, and samples were collected. Despite the difficulties of fieldwork in the El Salvador tropical area, we found the necessary outcrops to fulfill the goals of this study. A Digital Elevation Model (DEM) with $10 \mathrm{~m}$ precision was used as a topographic base map. Nearly 85 stratigraphic sections were measured, and several samples were collected for ${ }^{40} \mathrm{Ar} /{ }^{39} \mathrm{Ar}$ and U-Pb dating, for petrographic analysis in thin sections, and for major and trace element analyses. Geographic coordinates were recorded with a portable GPS (UTM projection system, Datum: D_WGS_1984, zone 16P). Samples were or- ganized and classified in the Observatorio Ambiental of the Ministerio de Medio Ambiente y Recursos Naturales (MARN) of El Salvador, packed and sent to the Centro de Geociencias (CGEO) of the Universidad Nacional Autónoma de México (UNAM) in Querétaro, Mexico. Results of the geochronologic, petrographic and geochemical analyses are described in Section 4. Prior to sample preparation for both chemical and geochronological analysis, samples were inspected for purity and freshness with the binocular microscope, and then in thin sections for petrographic analysis.

\subsection{Geochronology techniques}

Zircon crystals were separated and dated by U-Pb isotopic analysis at the Laboratorio de Estudios Isotópicos (LEI) of CGEO-UNAM, using a $193 \mathrm{~nm}$ Resolution M50 laser ablation inductively coupled plasma mass spectrometer (LA-ICP-MS) Thermo ICAP Qc following the method described in Solari et al. (2010) and Ortega-Obregón et al. (2013). Pumice fragments were separated from the different units, removing altered surfaces and then crushed and sieved to fractions of $74-44 \mu \mathrm{m}$. This fraction was then washed using a plastic pan to concentrate the heavy crystals from the lighter glass. Mineral concentrates were magnetically separated by means of a Frantz Isodynamic Separator to further concentrate the zircons. Representative zircons were handpicked under a binocular microscope and checked for purity and zoning using an ELM-3R luminoscope by cathodoluminescence, before and after the ICP-MS laser ablation analysis. About 50 zircon grains per sample were selected in order to obtain a statistically representative age.

Samples for ${ }^{40} \mathrm{Ar} /{ }^{39} \mathrm{Ar}$ dating were sent directly to the Oregon State University, Corvallis, U.S.A., for analysis in the OSU Argon Geochronology Laboratory. As with zircons, clean pumice clasts were separated and crushed to obtain mineral concentrations. Crushed samples were sieved to $500-177 \mu \mathrm{m}$ fractions and washed with deionized water using an ultrasonic bath to remove dust. Feldspars were magnetically separated from amphiboles and pyroxenes, and all phases were acid-leached following methods of Koppers et al. (2011). Sanidine or orthoclase is the preferred mineral phase in ${ }^{40} \mathrm{Ar} /{ }^{39} \mathrm{Ar}$ dating of young tephras. Unfortunately, no high-potassium feldspar was found in any of the IC samples. The only available phases to date were plagioclase and hornblende (ultra-pure separates picked clean of melt inclusion-rich crystals) and groundmass concentrations (lava samples). Incremental heating technique on bulk samples was employed to examine each phase analyzed. We used concentrates of the minerals since individual grains do not yield enough radiogenic argon for accurate single-crystal total fusion analyses (Rose et al., 1999). To achieve the highest possible precision in the ${ }^{40} \mathrm{Ar} /{ }^{39} \mathrm{Ar}$ age determinations, a large number of heating steps (22-33 heating steps) were carried out for each sample (Koppers et al., 2011). Age plateaus were chosen including as many contiguous and concordant step ages as possible. Before analyzing a sample, and after every three heating steps, system blanks were measured. In this way, after the first 7 to 14 low temperature steps, an adequate amount of discordant gases was released from alterations remaining and atmospheric contamination. To get the appropriate eruption timing it was necessary to recalculate the ages using the Kuiper et al. (2008) age for the Fish Canyon Tuff as flux monitor, reducing the data with the ArArCALC v2.5.1 software from Koppers (2002). All ${ }^{40} \mathrm{Ar} /{ }^{39} \mathrm{Ar}$ age errors reported here are $2 \sigma$. More details of the techniques employed in the dating process are provided in Appendix B and in Koppers et al. (2011). 


\subsection{Geochemistry}

Chemical analyses were performed on whole-rock pumices that were previously dried in an oven at $90^{\circ} \mathrm{C}$ for $24 \mathrm{~h}$ and hand-cleaned by removing the weathered surface under careful clean conditions to avoid contamination. Samples were crushed and grinded by hand using an agate ceramic mortar, until a homogenous powder with -200 mesh size was obtained using new plastic mesh for research standards in each sample. Major, trace, and Rare Earth-Elements (REE) were obtained. Major and some trace elements were measured by means of X-Ray Fluorescence (XRF) technique in the laboratory of Instituto de Geología, UNAM (Mexico), using a X RIGAKU ZSX Primus II spectrometer. REE and other trace element analyses were obtained by ICP-MS in the LEI of CGEO. Method of sample handling and analyses techniques are described in Bernal and Lozano-Santacruz (2005).

\section{Results}

\subsection{Stratigraphy and distribution of the early Ilopango caldera ignimbrites}

The systematic geologic mapping and volcanic stratigraphy carried out on IC deposits has allowed for the identification and characterization of the three lowermost explosive eruptions from IC. They comprise broadly distributed Quaternary pyroclastic deposits, from oldest to youngest: Olocuilta, Colima and Apopa ignimbrites. They consist of widespread ignimbrite sheets covering the central portion of El Salvador (Fig. 2).

\subsubsection{Olocuilta Ignimbrite (OI)}

The first volcanic eruption from IC occurred at $1.785 \pm 0.006 \mathrm{MaBP}$ (Ar/Ar age, Section 4.3 of geochronology results) and produced the high-K rhyolitic OI (Table 1). This pyroclastic deposit consists mostly of large pumice ( $40 \%$ vesicles), and lithics (15-25\% total volume) in an ash matrix. In general, the pumices contain phenocrysts of plagioclase, quartz, pyroxenes and Fe-Ti oxides with accessory zircon and apatite. OI overlies a sequence of volcano-clastic sediments deposited over the Zaragoza Ignimbrite (Weyl, 1957), which is an older andesitic-dacitic tuff from Jayaque Caldera (Fig. 3). OI is light red to pink due to the alteration of the ferromagnesian components. At ILO-73, near the town of Olocuilta, the contact between the top of OI and the base of $\mathrm{CoI}$ is exposed (Figs. 2, 3 and $4 d)$.

OI shows a basal thin layer of pumice-lapilli fall between 30 and $25 \mathrm{~cm}$ overlaid by tens of meters of a massive ignimbrite unit (Fig. 4a), forming a thick deposit observable at distances of up to $30 \mathrm{~km}$ from the caldera (e.g., at ILO-184, Fig. 2). Diffuse internal stratification is marked by lenses of pumice (PlensL, Figs. 3 and $4 \mathrm{e}$ ). The ignimbrite shows a 1-3 $\mathrm{m}$ thick basal pumice breccia $(\mathrm{PmBr}$, Fig. 3 ), containing pumice up to $20 \mathrm{~cm}$ in diameter. The middle zone of the OI is a lithic-rich, massive lapilli tuff (mLTl, Fig. 3), at the medial to proximal facies on the northern flank of IC, with lithics of $15 \mathrm{~cm}$ (ILO-251, ILO-10 and ILO-219, Fig. 2). At the top of OI and in particular in the southern outcrops, it is welded $8-10 \mathrm{~m}$ thick, with columnar jointing (Fig. 4b). Welding reaches from partially (eutaxitic texture, with pumice lapilli collapse, ILO-64; Figs. 2, 4f and 6a), to

Table 1

Whole-rock chemistry of OI, CoI and ApI pumices.

\begin{tabular}{|c|c|c|c|c|c|c|c|c|c|c|c|}
\hline Sample & ILO-199 & ILO-313 & ILO-21 & ILO 36-A & ILO-64 & ILO-184 & ILO-36-B & ILO-82 & ILO-73 & ILO-134 & ILO-78 \\
\hline Unit & OI & OI & OI & OI & OI & OI & $\mathrm{CoI}$ & $\mathrm{CoI}$ & $\mathrm{CoI}$ & ApI & ApI \\
\hline $\mathrm{SiO}_{2}$ & 74.9 & 76.3 & 75.0 & 74.6 & 75.9 & 74.8 & 71.9 & 72.5 & 72.2 & 71.9 & 71.8 \\
\hline $\mathrm{TiO}_{2}$ & 0.13 & 0.11 & 0.13 & 0.16 & 0.13 & 0.12 & 0.35 & 0.35 & 0.39 & 0.30 & 0.29 \\
\hline $\mathrm{Al}_{2} \mathrm{O}_{3}$ & 14.9 & 13.0 & 14.1 & 14.9 & 13.7 & 14.8 & 14.9 & 14.5 & 15.3 & 15.3 & 14.3 \\
\hline $\mathrm{FeO}^{*}$ & 1.48 & 1.27 & 1.54 & 1.71 & 1.42 & 1.70 & 2.45 & 2.36 & 2.76 & 3.09 & 3.19 \\
\hline $\mathrm{MnO}$ & 0.08 & 0.06 & 0.06 & 0.06 & 0.06 & 0.06 & 0.09 & 0.10 & 0.10 & 0.11 & 0.10 \\
\hline $\mathrm{MgO}$ & 0.28 & 0.30 & 0.41 & 0.34 & 0.28 & 0.32 & 0.51 & 0.55 & 0.55 & 0.60 & 0.83 \\
\hline $\mathrm{CaO}$ & 1.14 & 1.12 & 1.21 & 1.14 & 1.11 & 1.16 & 1.63 & 1.54 & 1.54 & 2.20 & 2.85 \\
\hline $\mathrm{Na}_{2} \mathrm{O}$ & 2.38 & 2.06 & 2.30 & 2.43 & 2.14 & 2.87 & 2.64 & 2.66 & 2.56 & 3.53 & 3.71 \\
\hline $\mathrm{K}_{2} \mathrm{O}$ & 4.69 & 5.72 & 5.22 & 4.60 & 5.22 & 4.05 & 5.30 & 5.35 & 4.57 & 2.87 & 2.84 \\
\hline $\mathrm{P}_{2} \mathrm{O}_{5}$ & 0.03 & 0.03 & 0.03 & 0.03 & 0.03 & 0.03 & 0.06 & 0.07 & 0.07 & 0.08 & 0.09 \\
\hline LOI & 3.27 & 2.56 & 4.58 & 2.22 & 3.87 & 4.24 & 4.25 & 3.89 & 5.34 & 4.19 & 5.54 \\
\hline SUM & 99.9 & 99.9 & 100.1 & 99.8 & 99.9 & 99.8 & 100.1 & 99.9 & 99.9 & 99.9 & 99.7 \\
\hline $\mathrm{Rb}$ & 87 & 107 & 106 & 94 & 105 & 85 & 126 & 117 & 125 & 48 & 43 \\
\hline $\mathrm{Sr}$ & 114 & 111 & 123 & 119 & 114 & 117 & 180 & 160 & 179 & 208 & 190 \\
\hline $\mathrm{Ba}$ & 1212 & 1146 & 1297 & 1200 & 1322 & 1242 & 1163 & 1211 & 1172 & 1100 & 956 \\
\hline $\mathrm{Y}$ & 17 & 19 & 17 & 15 & 15 & 18 & 37 & 32 & 36 & 19 & 11 \\
\hline $\mathrm{Zr}$ & 104 & 89 & 114 & 123 & 106 & 102 & 301 & 273 & 323 & 210 & 92 \\
\hline $\mathrm{Nb}$ & 5 & 5 & 4 & 3 & 2 & 5 & 7 & 5 & 6 & 5 & 3 \\
\hline V & 5 & 4 & 8 & 11 & 19 & 6 & 17 & 12 & 15 & 15 & 23 \\
\hline $\mathrm{Cr}$ & 0 & 0 & $<3$ & 4 & 9 & 0 & 0 & $<3$ & $<3$ & 1 & $<3$ \\
\hline $\mathrm{Co}$ & 2 & 2 & 5 & 8 & 3 & 3 & 4 & 7 & 8 & 5 & 8 \\
\hline $\mathrm{Ni}$ & 7 & 7 & 10 & 10 & 10 & 8 & 7 & 9 & 10 & 7 & 8 \\
\hline $\mathrm{Cu}$ & 5 & 7 & 20 & 13 & 12 & 12 & 7 & 10 & 10 & 19 & 10 \\
\hline $\mathrm{Zn}$ & 29 & 13 & 35 & 30 & 34 & 28 & 51 & 54 & 58 & 54 & 43 \\
\hline Th & 7 & 6 & 8 & 7 & 8 & 7 & 7 & 8 & 10 & 3 & 3 \\
\hline $\mathrm{Pb}$ & 11 & 7 & 8 & 7 & 9 & 9 & 14 & 12 & 15 & 8 & 5 \\
\hline$X(m)$ & 274,665 & 275,498 & 272,823 & 256,099 & 272,901 & 316,801 & 256,099 & 269,885 & 270,915 & 304,297 & 264,763 \\
\hline $\mathrm{Y}(\mathrm{m})$ & $1,501,091$ & $1,493,097$ & $1,495,122$ & $1,493,793$ & $1,494,947$ & $1,520,480$ & $1,493,793$ & $1,554,548$ & $1,500,438$ & $1,516,540$ & $1,526,998$ \\
\hline
\end{tabular}

OI: Olocuilta Ignimbrite, CoI: Colima Ignimbrite, ApI: Apopa Ignimbrite.

Major elements in $\mathrm{wt} \%$ and trace elements in ppm.

Samples analyzed by X-Ray Fluorescence in the Insituto de Geología (UNAM) by Patricia Girón.

Coordinates in WGS84 system (zone 16P).

$\mathrm{FeO}^{*}$-total iron; LOI: Lost of ignition. 


\begin{tabular}{|c|c|c|c|c|c|c|}
\hline \multicolumn{4}{|c|}{ Formation/ Units/Thickness (m) } & Lithofacies & Lithology and Volcanic phase & Age (Ma) \\
\hline & 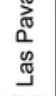 & $\stackrel{n}{\sim}$ & & Lavaf & $\begin{array}{l}\text { porphyritic lava flow (effusive } \\
\text { post-collapse volcanism) }\end{array}$ & $\begin{array}{l}1.34 \pm 0.02 \\
\mathrm{Ma}(\mathrm{Ar} / \mathrm{Ar})\end{array}$ \\
\hline 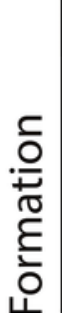 & 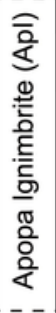 & $\begin{array}{l}\stackrel{N}{+} \\
+\end{array}$ & $5 \underset{\cdots \cdots 3}{\ldots \ldots, 3}$ & $\begin{array}{l}\text { Paleosol } \\
\text { cmLTI } \\
\mathrm{mIBr} \\
\mathrm{mLT} \\
\mathrm{mpL} \\
\text { IlbsT (accL) }\end{array}$ & $\begin{array}{l}\text { consolidated massive lapilli } \\
\text { tuff (incipient welding, rank II) } \\
\text { massive lithic Breccia (Co- } \\
\text { ignimbrite breccia: caldera } \\
\text { collapse) } \\
\text { massive lapilli (pumice fall) } \\
\text { parallel bedded stratified } \\
\text { tuff with accretionary lapilli } \\
\text { (hydromagmatic surges) }\end{array}$ & $\begin{array}{l}\text { (not available } \\
\text { due to } \\
\text { unsuccessful } \\
\text { dating results) }\end{array}$ \\
\hline 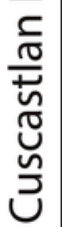 & 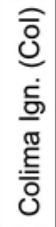 & ㅇำ & & $\begin{array}{c}\text { Paleosol } \\
\mathrm{mLT} \\
\mathrm{pmBr} \\
\mathrm{mLT} \\
\mathrm{mpL}\end{array}$ & $\begin{array}{l}\text { massive lapilli tuff (PDCs) } \\
\text { pumice massive breccia with } \\
\text { crystal mush (possible collapse) } \\
\text { massive lapilli (pumice fall) }\end{array}$ & $\begin{array}{l}1.55 \pm 0.12 \\
\mathrm{Ma}(\mathrm{U} / \mathrm{Pb}) \\
1.56 \pm 0.01 \\
\mathrm{Ma}(\mathrm{Ar} / \mathrm{Ar})\end{array}$ \\
\hline & 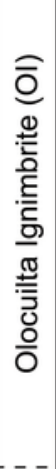 & & $: 0$ & $\begin{array}{c}\text { Paleosol } \\
\mathrm{mLT} \\
\text { Eutx } \\
\mathrm{mLTI} \\
\mathrm{mLT} \\
\text { plensL } \\
\mathrm{mLT} \\
\mathrm{pmBr} \\
\mathrm{mpL}\end{array}$ & $\begin{array}{l}\text { massive lapilli tuff (PDCs) } \\
\text { eutaxitic texture and columnar } \\
\text { jointing (moderately to high } \\
\text { welding, rank IV-V) } \\
\text { massive lapilli tuff lithic-rich } \\
\text { (energetic PDC's, opening } \\
\text { conduit and possible collapse) } \\
\text { pumice rich lense lapilli (marker } \\
\text { between differents PDCs) } \\
\text { massive lapilli tuff (PDCs) } \\
\text { pumice massive breccia } \\
\text { (beginning of PDC's eruption) } \\
\text { massive lapilli (pumice fall) }\end{array}$ & $\begin{array}{l}1.64 \pm 0.19 \\
\mathrm{Ma}(\mathrm{U} / \mathrm{Pb}) \\
1.785 \pm 0.006 \\
\mathrm{Ma}(\mathrm{Ar} / \mathrm{Ar})\end{array}$ \\
\hline & 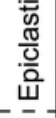 & $\stackrel{\infty}{\sim}$ & 覚 & V.clast & $\begin{array}{l}\text { Volcanoclastic reworked } \\
\text { material (epiclastic deposits } \\
\text { during volcanic hiatus) }\end{array}$ & \\
\hline 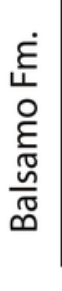 & 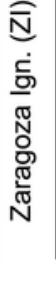 & $\begin{array}{l}\text { o } \\
+\end{array}$ & 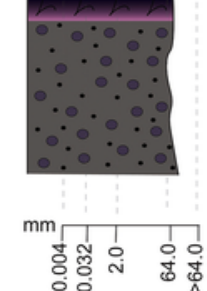 & $\begin{array}{l}\text { Paleosol } \\
\text { mLT } \\
\text { BNE }\end{array}$ & $\begin{array}{l}\text { massive lapilli tuff (PDCs from } \\
\text { Jayaque Caldera, dark andesitic- } \\
\text { dacitic pyroclastic deposits) } \\
\text { Base not exposed }\end{array}$ & $\begin{array}{l}\sim 2.4 \mathrm{Ma} \\
\text { (K/Ar, Lexa } \\
\text { et al., 2010) }\end{array}$ \\
\hline
\end{tabular}

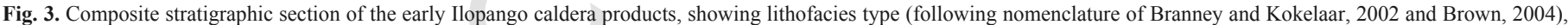
interpretation and age for each deposit. (For interpretation of the references to colour in this figure legend, the reader is referred to the web version of this article.)

densely welded (with fiammes, ILO-96; Figs. 2 and 6b), being IV-V of Quane and Russell (2005) rank. The welded top of OI acted as a resistant caprock that protected the unconsolidated lower zones of this ignimbrite from erosion and formed an extensive plateau that dominates the geomorphology of the Balsamo Mountain Range (Figs. 2 and $4 \mathrm{c}$ ). Perennial streams have incised deeply this plateau reaching the basement rocks (lavas and volcanic breccias of the Balsamo formation). Some of these canyons expose entire stratigraphic sections of the OI up to $100 \mathrm{~m}$ thick such as exposures in ILO-192 (Figs. 2 and $4 \mathrm{c}$ ). Above the welded level, there is an additional $25 \mathrm{~m}$ of non- welded ignimbrite that is indurated by vapor-phase silicification (ILO-180; Fig. 2), indicating a total thickness of $\sim 125 \mathrm{~m}$ for OI.

\subsubsection{Colima Ignimbrite (CoI)}

The second large explosive eruption from IC occurred at $1.57 \pm 0.01 \mathrm{MaBP}$ (Ar/Ar age, see Section 4.3 of geochronology results) producing the CoI, which is a high-K rhyolitic unit (Table 1) with plagioclase, hornblende, and accessory minerals of apatite, zircon and Fe-Ti oxides. This ignimbrite, like the previous one, starts with a thin layer of pumice-lapilli fallout overlying the paleosol developed at the top of OI (e.g. ILO-73 and ILO-36; Figs. 2, 3, 4d and 

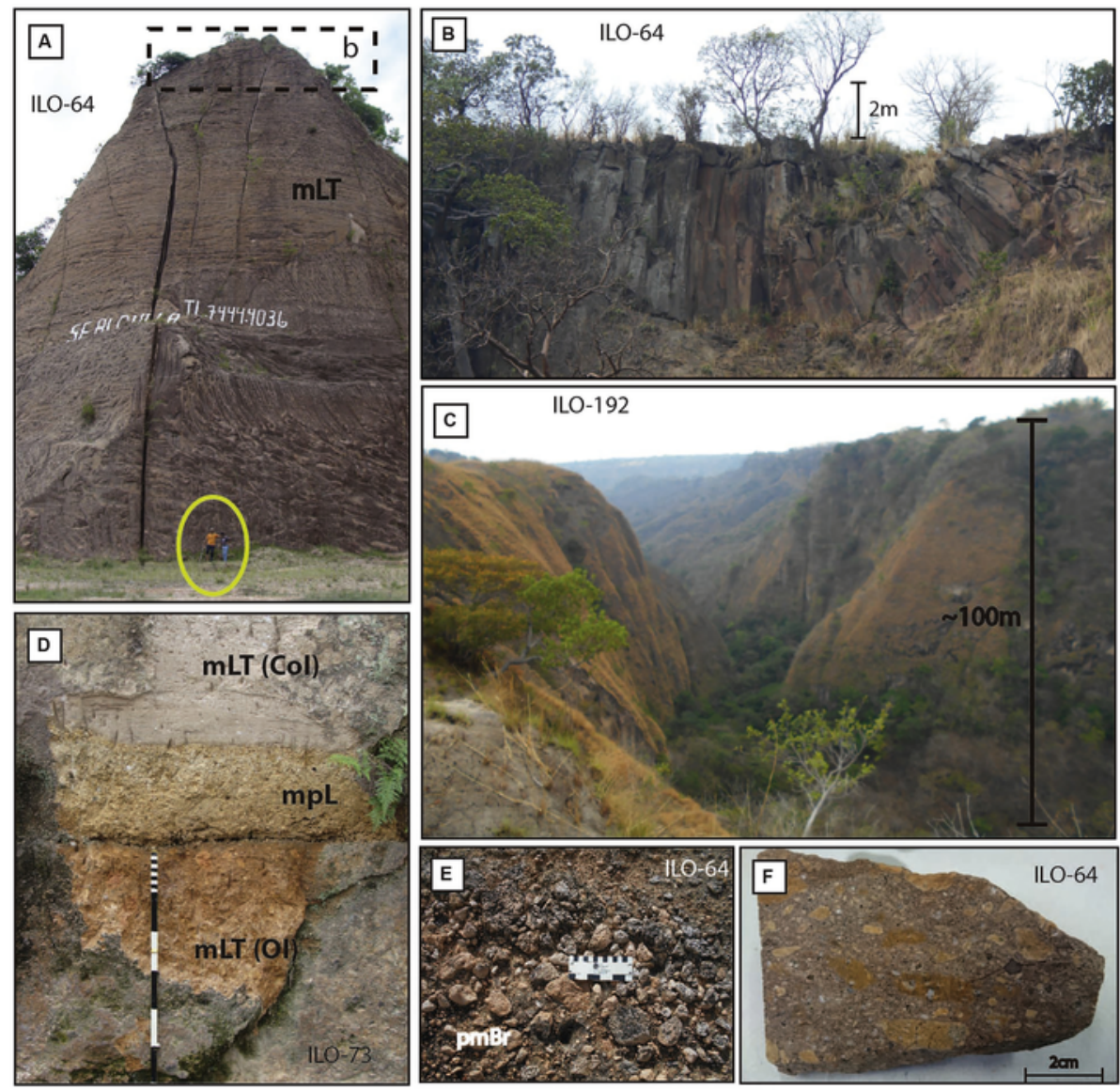

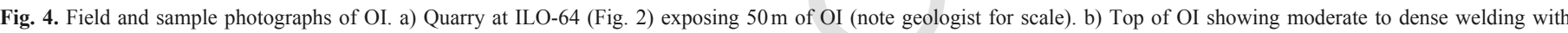

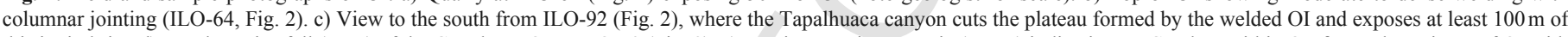

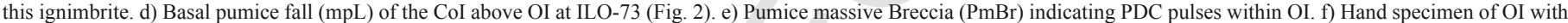
eutaxitic texture sampled at ILO-64 (Rank IV of welding intensity scale, Quane and Russell, 2005; Fig. 2).

5b). Above this basal layer, there is a sequence of pyroclastic density currents (PDC) deposits composed mostly of a pale grey ash matrix with large white and highly vesiculated pumice (50 vol\%), and minor amounts of lithics. This ignimbrite traveled distances of up to $40 \mathrm{~km}$ to the north of the caldera, reaching the Lempa River Water Reservoir (ILO-82; Figs. 2 and 5a). In proximal facies of the caldera it is very difficult to find outcrops where the CoI stratigraphic section is completely exposed due to the heavy vegetation and because this unit is covered by younger Ilopango tuffs. However, in medial facies like at the ILO-150 (Fig. 2), there are at least $19 \mathrm{~m}$ of this deposit are observable.

There is no evidence of lithic breccias or welded zones in the $\mathrm{CoI}$ and, in general, it is an unconsolidated tuff easily eroded by the tropical rains of El Salvador's weather, mainly on the steep slopes of the southern flank of IC, where the ignimbrite is sporadically exposed. The CoI is relatively massive, with large pumices concentration zones, generally at the base and middle part of the unit forming pumiceous breccias ( $\mathrm{pmBr}$ in Fig. 3, pumice of $\sim 20 \mathrm{~cm}$ ). Within these breccias there are pieces of intrusive cognate blocks among the components (e.g., at ILO-101; Figs. 2 and 5c). These are vesiculated fragments of crystalline igneous rock with $50 \%$ total volume in crystals with a non-fragmented vesiculated glass matrix (Fig. 6c). Polished thin sections of these enclaves show glomeroporphyritic texture with plagioclase and hornblende (Fig. 6d), and poikilitic texture with small hornblende within plagioclase large phenocrysts (Fig. 6e). We infer that these cognate blocks are crystal mush clasts, which correspond to broken pieces of the subcaldera magma chamber wall.

\subsubsection{Apopa Ignimbrite (ApI)}

The third large explosive eruption associated with IC produced the ApI at 1.34 MaBP (age of a overlaying lava, see Section 4.3). This ignimbrite is a medium-K rhyolitic tuff (see Table 1) with plagioclase and hornblende as principal phases and minor amounts of biotite and clinopyroxene, with accessory zircon, apatite and Fe-Ti oxides. At the base of ApI there is a sequence of sub-parallel dilute PDC deposits (llbsT, surge deposits; Fig. 3) mostly composed of fine, yellow-white ash and accretionary lapilli, and small fragmented clasts of pumice (ILO-175; Figs. 2, 5d and e). The matrix is highly fragmented ash tuff, with sparse complete glass shards, and fine interstitial ash-dust and tiny fragments of the mineral assemblage (Fig. 6f). These fine-grained deposits of the ApI eruption resemble soft clay, probably due to the content of zeolites or other alteration minerals. They reach up to $5 \mathrm{~m}$ in thickness, with diffuse cross-lamination and load structures (flames in ILO-327, Figs. 2 and 5g).

Directly above these laminated deposits there are: 1) a thin layer of orange pumice-lapilli ( $\mathrm{mpL})$, rich in crystals (10-15 vol\%), with mostly hornblende and plagioclase, and 2) a sequence of denser lithic-rich PDCs deposits (mLT, Fig. 5d). These PDCs of the upper part of the ApI show a diffuse internal stratification with several pumice-rich horizons (plensL) and a lithic breccia layer ( $\mathrm{mlBr}$ ). This breccia can be correlated in several proximal outcrops to the north of 

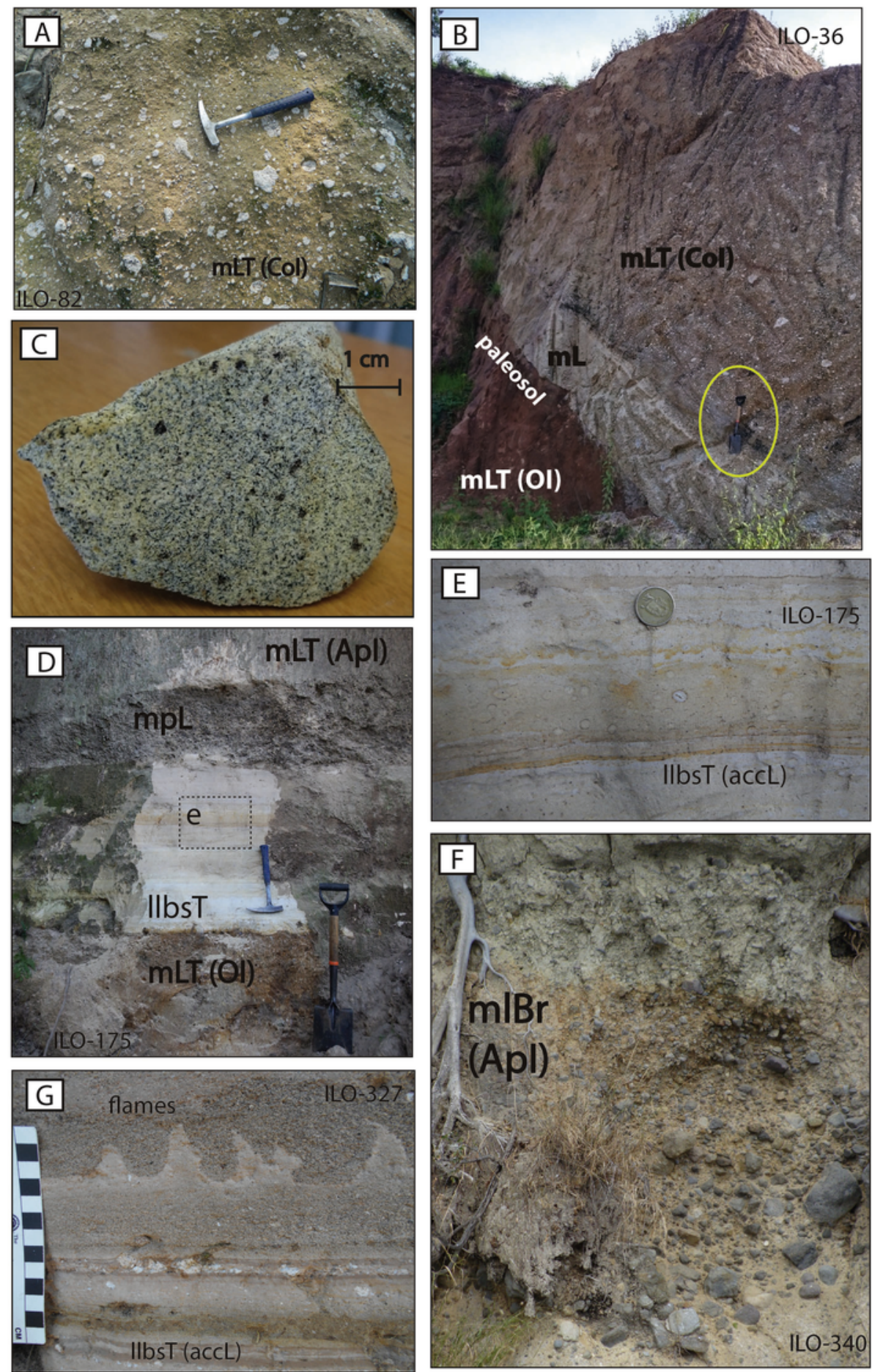

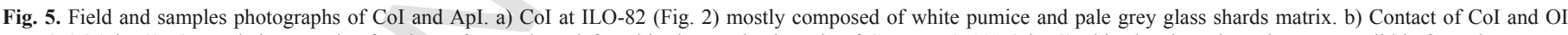

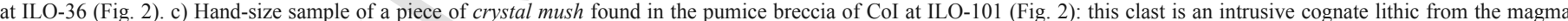

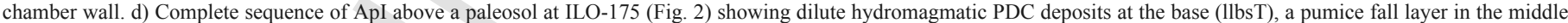

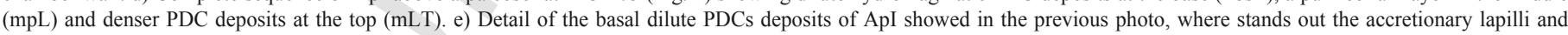

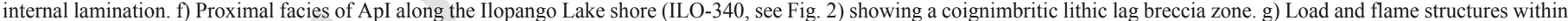
the dilute PDC deposits at the base of ApI at ILO-327 (Fig. 2).

IC and it is also observed also along the shore of the Ilopango Lake, where angular lithics can be as large as $50 \mathrm{~cm}$ in diameter (ILO-145, ILO-225 and ILO-340, Figs. 2 and 5f). The ApI is the first IC ignimbrite that contains a heterolithological lithic breccia, with lava and plutonic lithic clasts, interpreted as a coignimbrite lithic lag breccia (ILO-89; Figs. 2 and 5g). The ApI reaches as far as the Lempa River Water Reservoir (ILO-82; Fig. 2), throughout a valley to the north for $\sim 40 \mathrm{~km}$. The accumulation of hot material filling this valley caused 

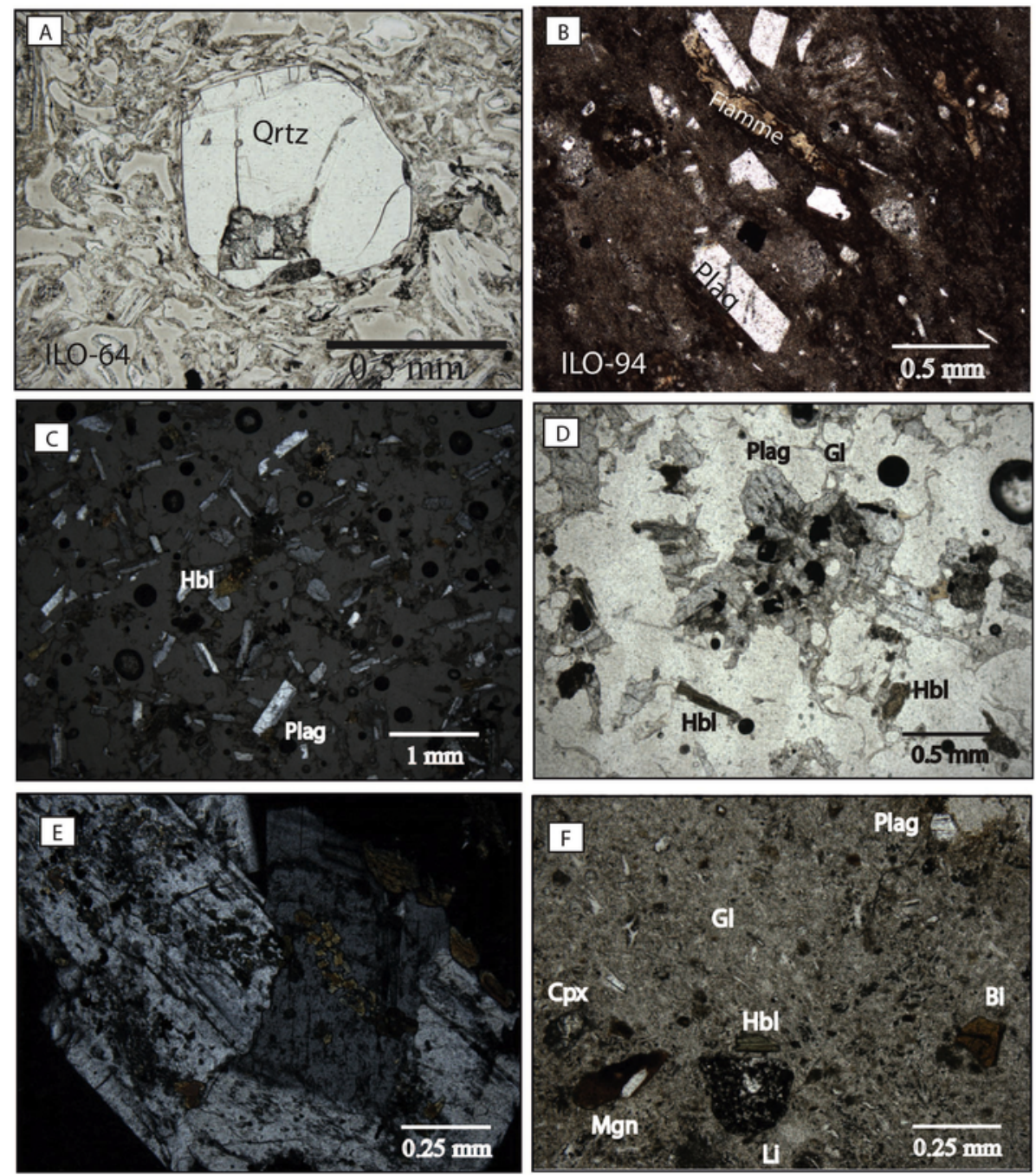

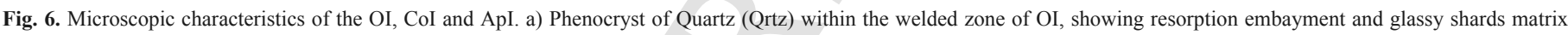

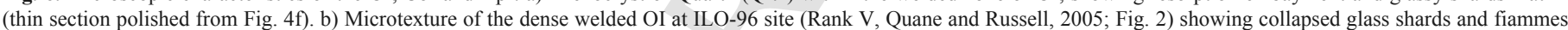

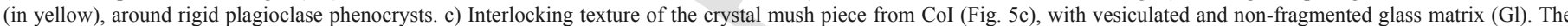

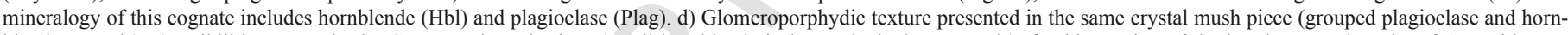

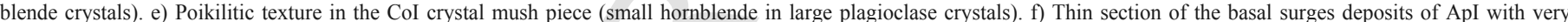

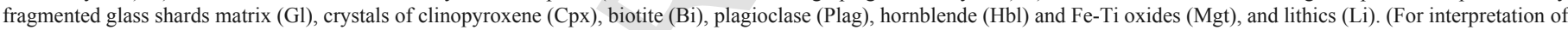
the references to colour in this figure legend, the reader is referred to the web version of this article.)

the incipiently welding of the top of ApI, with adhesion between clasts but remaining undeformed (rank II, Quane and Russell, 2005). At ILO-102, located about $20 \mathrm{~km}$ to the NW of IC (Fig. 2), this welded top level protected the underlying and unconsolidated tuff of ApI from erosion. At this site the ignimbrite reaches about $14 \mathrm{~m}$ of thickness. On the southern facies, as with the CoI, the ApI is sporadically exposed due to erosion. At some locations, (e.g., ILO-175, Fig. 2), the ApI is only covered by a consolidated lahar deposit that protected this ignimbrite from fluvial erosion (Fig. 5d).

\subsection{Geochemistry}

Whole-rock chemical analyses were carried out on pumice fragments collected from the three ignimbrites (Table 1) in order to obtain the geochemical characteristics of the earliest volcanic products of IC. The pyroclastic products of the IC are all subalkaline rhyolites with high $\mathrm{SiO}_{2}$ content (Fig. 7a), and high- $\mathrm{K}_{2} \mathrm{O}$ values for the first two eruptions (OI and $\mathrm{CoI}$ ), and medium content for the third one
(ApI, Fig. 7b). Harker variation diagrams (Fig. 8) show evolved magmas for the three ignimbrites, with OI as the most evolved, which is the richest in $\mathrm{SiO}_{2}$ and the poorest in total $\mathrm{FeO}$ and $\mathrm{MgO}$. From OI to $\mathrm{CoI}$ to ApI there is a tendency for a slightly less evolved magma. The three ignimbrites show the typical calcalkaline nature of subduction type magmas along continental margins, as elsewhere in CAVA (Arculus and Curran, 1972; Morris and Ryan, 2004; Murphy, 2007).

Abundances of the Rare Earth Elements (REE) and other key trace elements are displayed in a spider diagram (Fig. 9), in which the elements are arranged from left to right in order of increasing compatibility, and values normalized to Mid-Ocean Ridge Basalt values (MORB, Sun and McDonough, 1989). This diagram confirms the comagmatic origin for the three ignimbrites, with some features that can be used for correlation purposes. For example, the CoI generally has higher concentrations of REE than the other two ignimbrites and a notable negative anomaly in the $\mathrm{Sr}$ and $\mathrm{Eu}$. OI also has a negative anomaly in Sr but not in Eu. Finally, ApI has no Eu anomaly, and a positive $\mathrm{Sr}$ anomaly (Fig. 9). Negative Eu anomalies probably reflect 

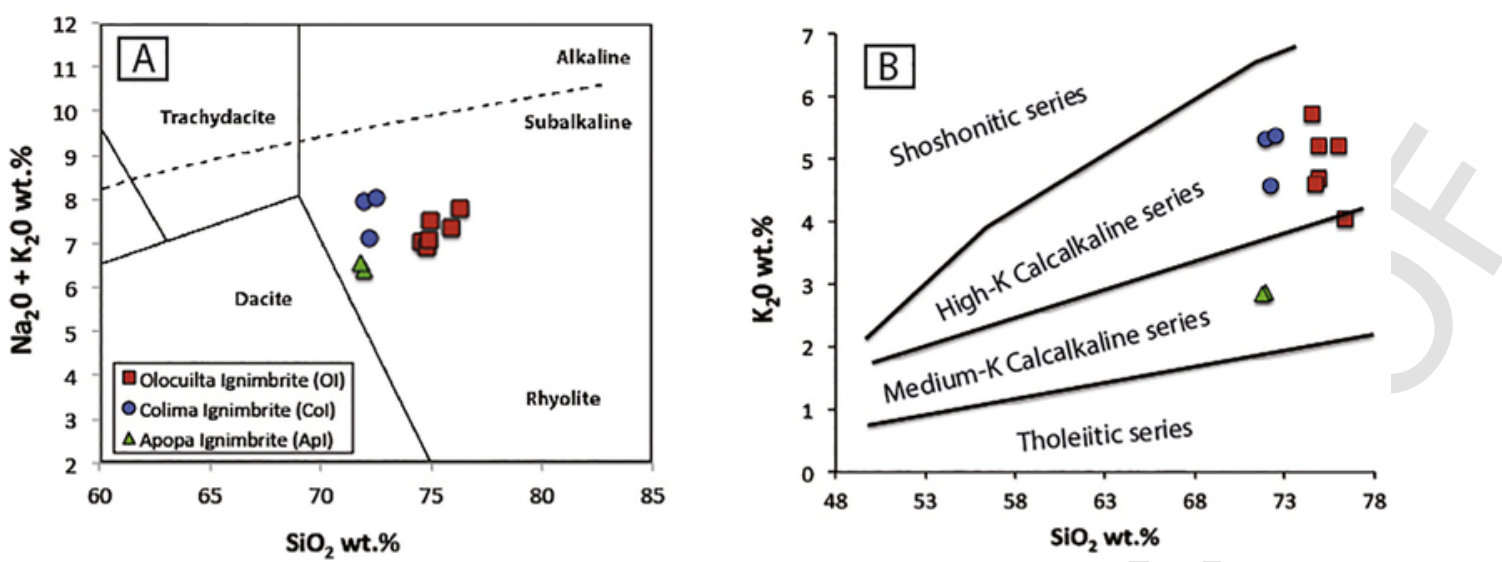

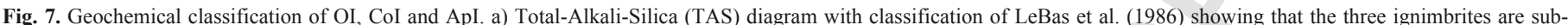

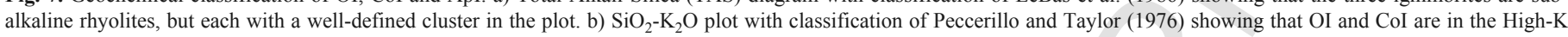
calcalkaline suite, and ApI in the Medium-K suite.
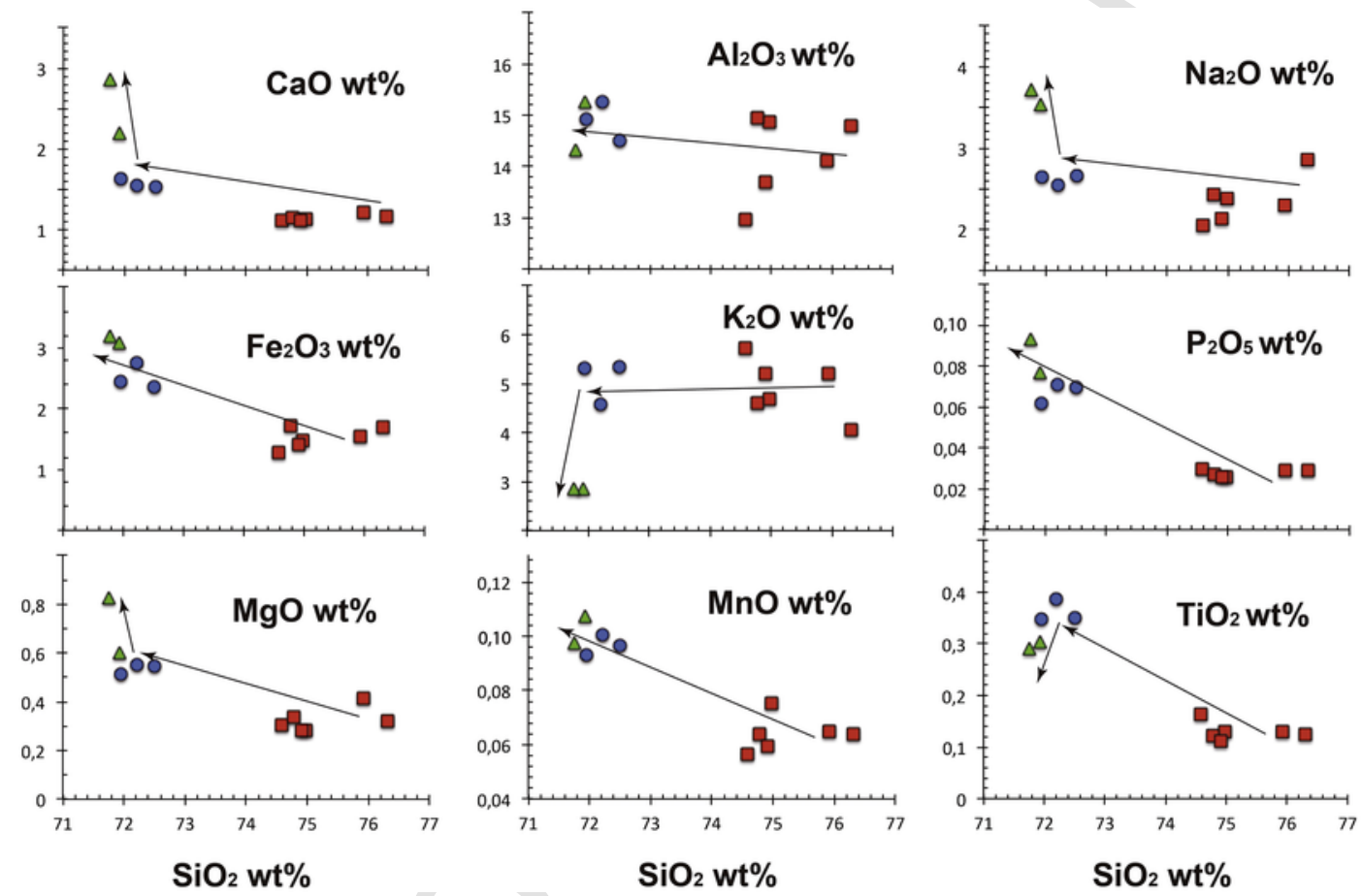

Fig. 8. Harker variation plots of OI, CoI and ApI. Note well-defined groups of each ignimbrite. Arrows indicate possible evolving trends (symbols as in Fig. 8).

plagioclase fractionation (Wilson, 1989). Plagioclase is the most abundant phenocryst in calcalkaline magmas, typically dominated over alkali feldspar (Murphy, 2007), as occurs in the Ilopango ignimbrites here described.

\subsection{Geochronology}

\subsection{1. $U / P b$ dating in zircon}

Four samples from the three first IC ignimbrites were collected for radiogenic $\mathrm{U}-\mathrm{Pb}$ zircon analyses, with a single sample from $\mathrm{OI}$ (ILO-64, Figs. 2 and 10a), two from CoI (ILO-73 and ILO-82, Figs. 2, $10 \mathrm{~b}$ and c), and one from ApI (ILO-78 site, Fig. 2). Analytical data are summarized in Appendix $\mathrm{A}$. The U-Pb zircon ages were obtained from the intersection of the Concordia curve with the normal isochron (Fig. 10a, b and c) using the Isoplot software (v. 3.7) and methods of Ludwig (2008). To obtain the best possible results, we discarded the most discordant zircons (largest ellipsoids in the isochron diagram). $\mathrm{U} / \mathrm{Pb}$ zircon age for $\mathrm{OI}$ yielded $1.64 \pm 0.19 \mathrm{Ma}$ (1.45-1.83 Ma range). The large error is caused probably because most zircons analyzed were too small $(<80 \mu \mathrm{m})$, which have xenocrystic cores with concentric zoning (Fig. 10d and e), and due the limitations of the $\mathrm{U}-\mathrm{Pb}$ method in such young zircons (all the errors of $\mathrm{U} / \mathrm{Pb}$ reported in this study refer to $2 \sigma$ standard deviation). The most probable age of the crystallization of this zircon age is close to $1.8 \mathrm{Ma}$.

The two samples of zircon analyzed for the CoI were collected from the proximal facies to the south of IC (ILO-73, Fig. 2) and at $40 \mathrm{~km}$ to the north of IC (ILO-82, Fig. 2). The zircon ages are $1.53 \pm 0.28 \mathrm{Ma}$ and $1.55 \pm 0.12 \mathrm{Ma}$, for southern and northern sites respectively, supporting the correlation of this ignimbrite between the 


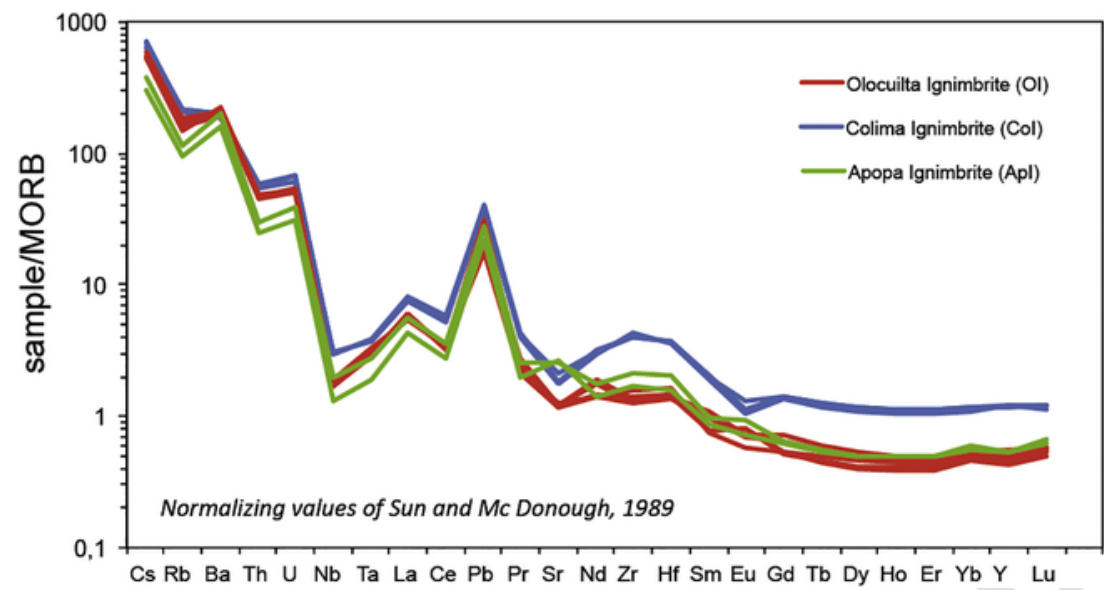

Fig. 9. Spider diagrams of OI, CoI and ApI normalized to MORB (Sun and McDonough, 1989) showing the REE abundances.
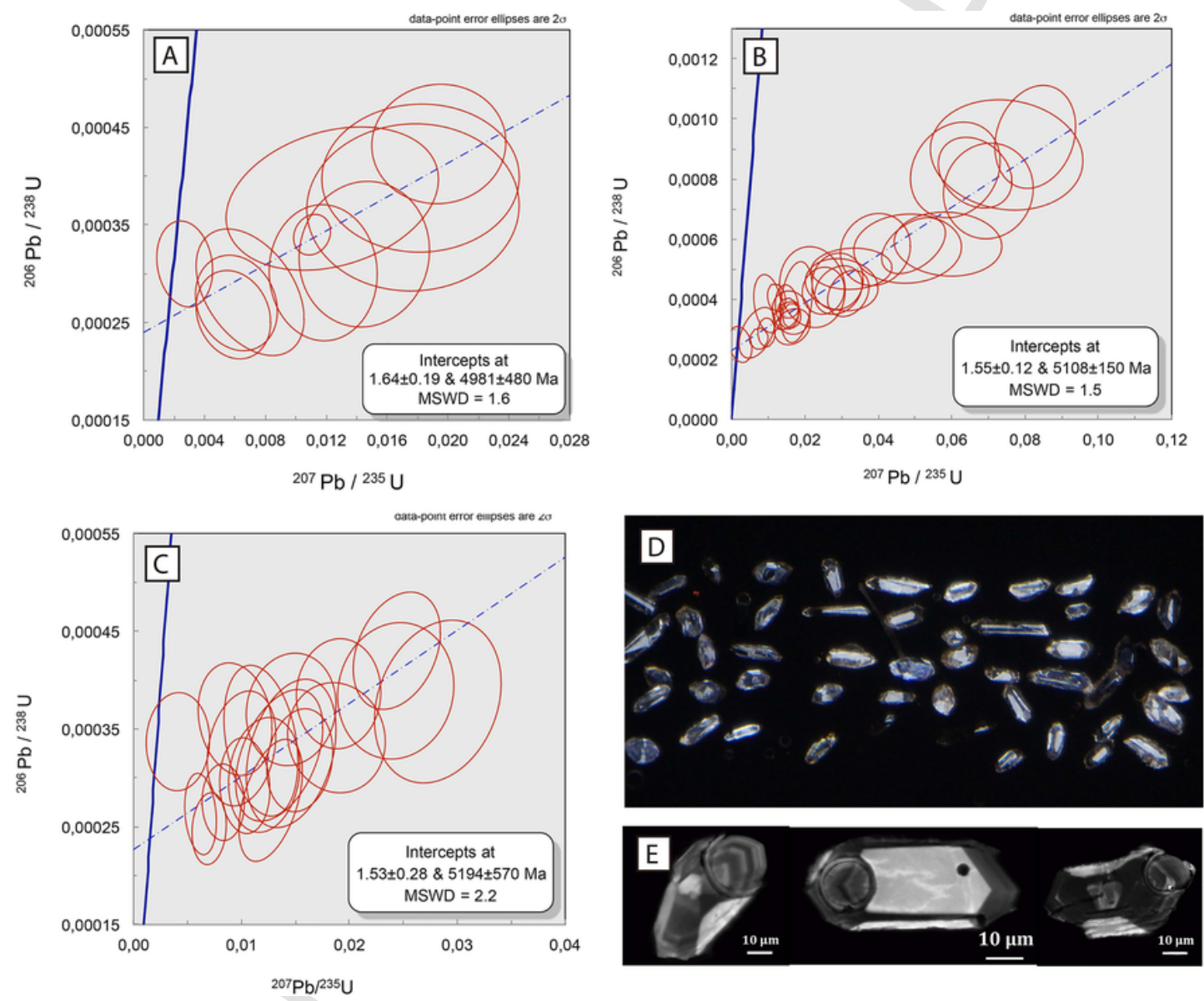

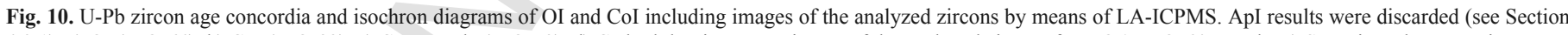

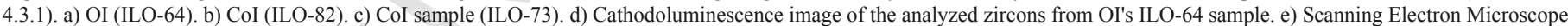
(SEM) image of zircons from OI's ILO-64 sample after laser ablation ICP-MS analyses.

proximal and distal facies (Fig. 10b and c). No age for ApI could be obtained possibly because of the low content in $\mathrm{U}$ and $\mathrm{Pb}$ for this ignimbrite (see the relative concentrations in the spider diagram of Fig. 9). Most ApI zircons were inherited from an old basement of around $70 \mathrm{Ma}$.

Zircon analyses in such young products as the IC ignimbrites yield imprecise results, so it was necessary to use another geochrono- logical method trying to better constrain the timing of each ignimbrite. We thus estimated ${ }^{40} \mathrm{Ar} /{ }^{39} \mathrm{Ar}$ ages.

\subsection{2. ${ }^{40} \mathrm{Ar}{ }^{39} \mathrm{Ar}$ dating}

Five new ${ }^{40} \mathrm{Ar} /{ }^{39} \mathrm{Ar}$ ages (Table 2 and Fig. 11) were obtained by incremental heating methods using the ARGUS-VI mass spectrometer. Five high-purity plagioclase concentrates were analyzed for the 
Table 2

Summary of incremental heating ${ }^{40} \mathrm{Ar} /{ }^{39} \mathrm{Ar}$ analyses on early Ilopango caldera products.

\begin{tabular}{|c|c|c|c|c|c|c|c|c|c|c|c|c|c|c|c|}
\hline \multicolumn{5}{|c|}{ Sample information } & \multicolumn{6}{|c|}{ Age spectrum } & \multicolumn{2}{|l|}{ Total fusion } & \multicolumn{3}{|c|}{ Inverse isochron analyses } \\
\hline Unit & Sample & $\mathrm{X}(\mathrm{m})$ & $\mathrm{Y}(\mathrm{m})$ & Material & Age $\pm 2 \sigma(\mathrm{Ma})$ & ${ }^{39} \operatorname{Ar}(\%)$ & $\mathrm{K} / \mathrm{Ca}$ & MSWD & $\mathrm{n}$ & $\mathrm{N}$ & Age $\pm 2 \sigma(\mathrm{Ma})$ & $\mathrm{K} / \mathrm{Ca}$ & $\mathrm{Age} \pm 2 \sigma(\mathrm{Ma})$ & 40/36 intercept & MSWD \\
\hline Olocuilta Ign. & ILO-63 & 271,353 & $1,497,223$ & Plagioclase & $1.785 \pm 0.006$ & 86.37 & 0.072 & 1.10 & 87 & 124 & $1.792 \pm 0.06$ & 0.073 & $1787 \pm 0,006$ & $291.80 \pm 3.46$ & 1.05 \\
\hline Colima Ign. & ILO-73-P & 270,915 & $1,500,438$ & Plagioclase & $1.57 \pm 0.01$ & 100 & 0.058 & 2.77 & 22 & 22 & $1.56 \pm 0.01$ & 0.058 & $1,58 \pm 0,01$ & $276,71 \pm 8,18$ & 1.47 \\
\hline Colima Ign. & ILO-73-H & 270,915 & $1,500,438$ & Hornblende & $1.56 \pm 0.01$ & 100 & 0.058 & 1.38 & 22 & 25 & $1.55 \pm 0.01$ & 0.058 & $1.57 \pm 0.02$ & $294.05 \pm 3.21$ & 1.39 \\
\hline Las Pavas Lava & ILO-43-P & 288,141 & $1,518,462$ & Plagioclase & $1.34 \pm 0.02$ & 92 & 0.030 & 1.39 & 19 & 28 & $1.37 \pm 0.01$ & 0.028 & $1.33 \pm 0.04$ & $303.55 \pm 21.24$ & 1.42 \\
\hline Las Pavas Lava & ILO-43-G & 288,141 & $1,518,462$ & Groundmass & $1.22 \pm 0.03$ & 41 & 0.345 & 1.97 & 11 & 33 & $1.27 \pm 0.01$ & 0.345 & $1.22 \pm 0.04$ & $295.36 \pm 1.40$ & 2.18 \\
\hline
\end{tabular}

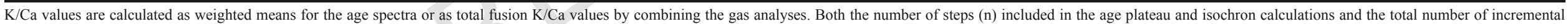

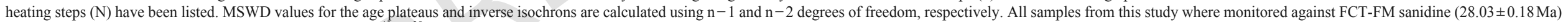
as calibrated by Kuiper et al. (1998). Reported errors on the ${ }^{40} \mathrm{Ar}{ }^{39} \mathrm{Ar}$ ages are at the $95 \%$ confidence level $(2 \sigma)$ including $0.3-0.4 \%$ standard deviation in the J-value. 

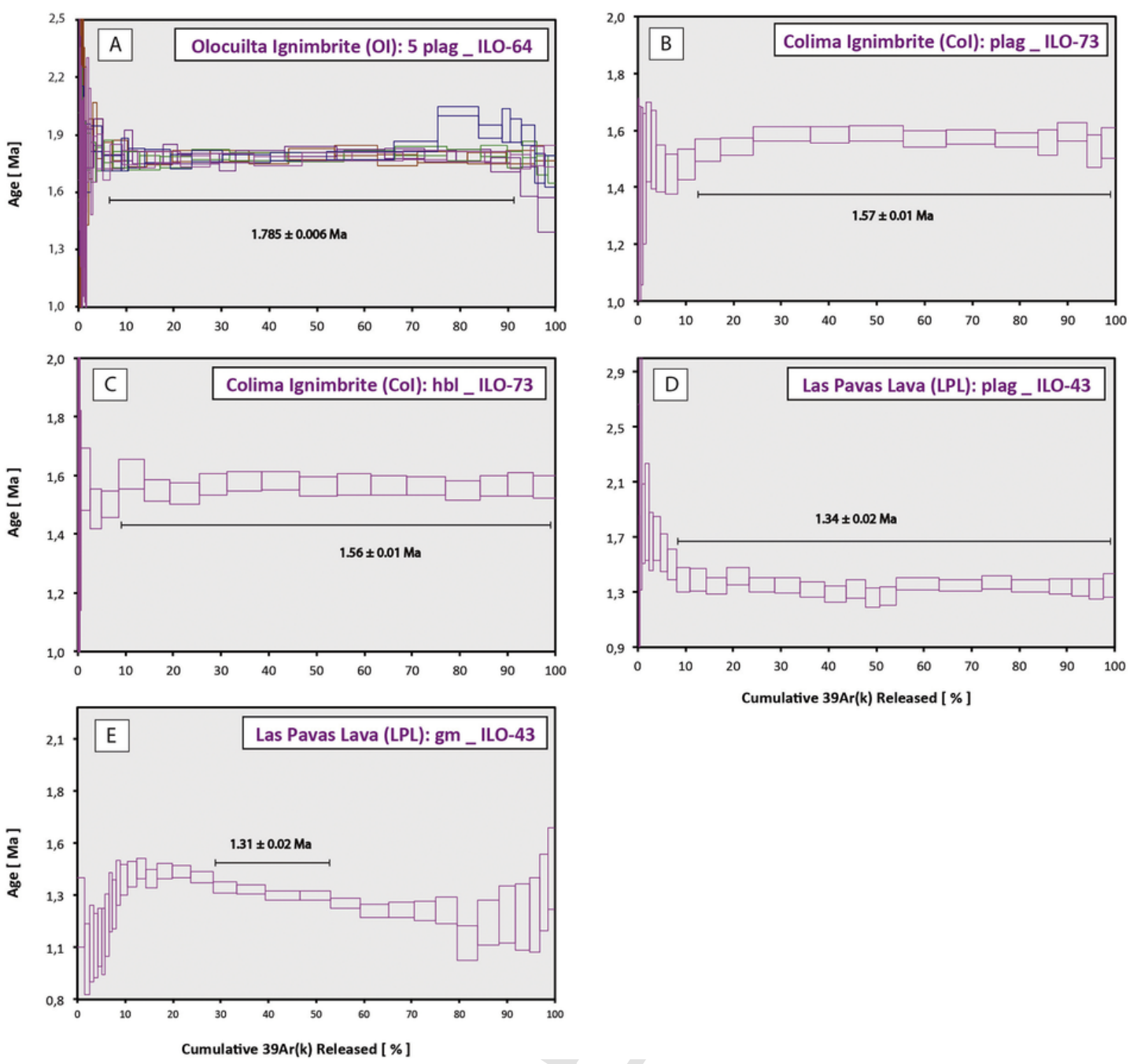

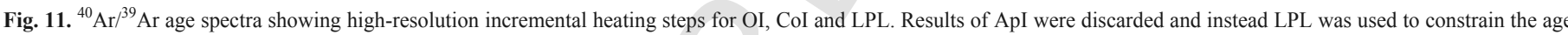

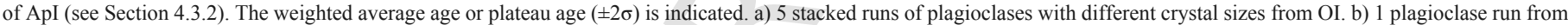
CoI. c) 1 hornblende run from the same CoI sample shown in b). d) 1 plagioclase run of LPL. e) 1 groundmass run of the same LPL sample of d).

OI (ILO-64 site; Fig. 2), which were then stacked to produce a new plateau age of $1.785 \pm 0.006 \mathrm{Ma}$ (Fig. 11a). This high-precision age of $\mathrm{OI}$ is within the analytical error of previous reported ages for this unit $(1.77 \pm 0.4 \mathrm{Ma}, 1 \sigma$; Lexa et al., 2011) and within the U-Pb zircon age reported above $(1.64 \pm 0.19 \mathrm{Ma} 2 \sigma)$. The CoI samples were analyzed by plagioclase and hornblende separates from the same site (ILO-73, Fig. 2), yielding 1.57 and $1.56 \pm 0.01 \mathrm{Ma}$, respectively (Fig. $11 \mathrm{~b}$ and c). This result agrees with the U-Pb zircon ages of this work (Fig. 10b and c).

No ${ }^{40} \mathrm{Ar} /{ }^{39} \mathrm{Ar}$ ages were obtained for the ApI because the hornblende and plagioclase yielded too much atmospheric argon to obtain reliable ages. Since these analyses were unsuccessful, we sampled the unit overlying ApI: Las Pavas Lava (LPL, Fig. 3), a post-caldera dome emplaced just after the eruption of ApI (ILO-43 site, Fig. 2). Plagioclase and a groundmass separates were analyzed for this lava (Fig. $11 \mathrm{~d}$ and e), yielding ages of $1.34 \pm 0.02 \mathrm{Ma}$ and $1.22 \pm 0.02 \mathrm{Ma}$ respectively. The LPL groundmass yielded a slightly younger age than the plagioclase age due to excess atmospheric argon. There is no well-developed paleosol at the top of this ignimbrite that contacts directly with the base of LPL, so the most probably age for the ApI is close to 1.34 Ma. Tables with all the analytical data of these Ar/Ar measurements are given in Appendix C.

\subsection{Stratigraphic correlation}

Stratigraphic descriptions, geological mapping and analytical results have allowed us to make a spatial and temporal correlation for the first 3 ignimbrites of IC (Fig. 12). Four profiles (A, B, C and D) containing representative measured stratigraphic sections (logs) show the thickness and distribution of the early IC ignimbrites, as well as the lithofacies changes from proximal to distal deposits from the caldera.

\section{Discussion}

\subsection{Volcanic phases of early ignimbrite-forming eruptions of Ilopango caldera}

OI represents the first and largest explosive eruption of IC, which began with a brief eruption column that deposited a thin layer of pumice-lapilli fall. This column collapsed apparently by depressurization due to the sudden opening and widening of the vent, from a central vent to a larger fissure vent possibly related to the extensional tectonics of the area (e.g., Aguirre-Díaz and Labarthe-Hernández, 

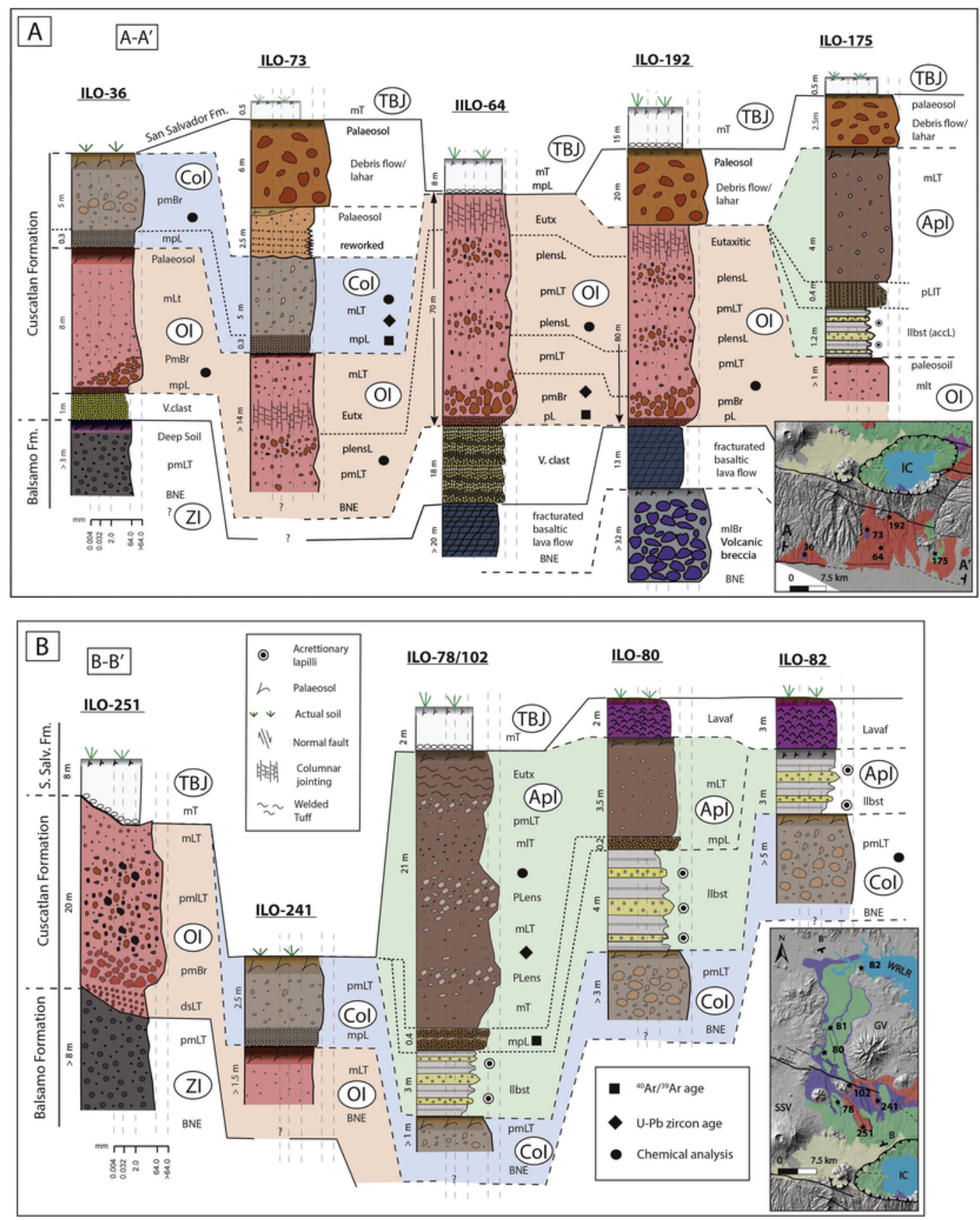

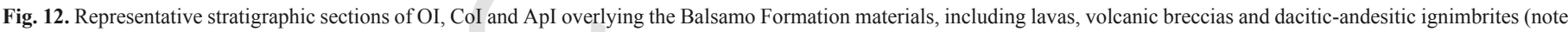

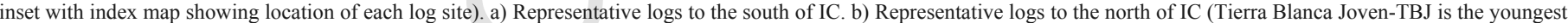

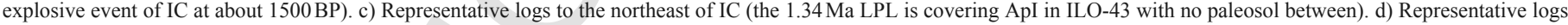
to the east of IC (note the San Vicente strike-slip Fault affecting the Carbonera caldera rim).

2003; Costa et al., 2011 and Section 5.3). The eruption then changed to extrusion of dense PDCs from the wider and larger fissure vent probably with a boiling-over style (e.g., Pacheco-Hoyos et al., 2018), as indicated by the pumice-rich nature of the OI and the long runout distances (Roche et al., 2016), which suggest lower explosivity and fragmentation of magma during eruption. At least $74 \mathrm{~km}^{3}$ of pyroclastic material equivalent to $50 \mathrm{~km}^{3}$ DRE came out of the vent (Section 5.2), filling the paleotopographic lows and covering a total area of about $3000 \mathrm{~km}^{2}$ with runouts of at least $40 \mathrm{~km}$. These PDCs were deposited continuously forming one single cooling unit, the massive OI.
To the south of the caldera this ignimbrite reached a thickness of $>100 \mathrm{~m}$ (ILO-192, Figs. 2 and 4c), forming a medium to intensely welded level and building a plateau that stands out in the geomorphology: the Balsamo Mountain Range (Figs. 2 and 4c). To the north, this ignimbrite is only slightly welded (ILO-251; Fig. 2), probably because $\mathrm{OI}$ in this lithofacies (Fig. 12b) is very rich in lava lithics that tend to cool the PDC deposit more rapidly (Marti et al., 1991). Lithic-rich proximal facies of the OI can be interpreted as coignimbritic lithic lag breccias (Branney and Kokelaar, 1997), indicating the proximity to the assumed fissure vent at or near the actual Ilopango lake. 

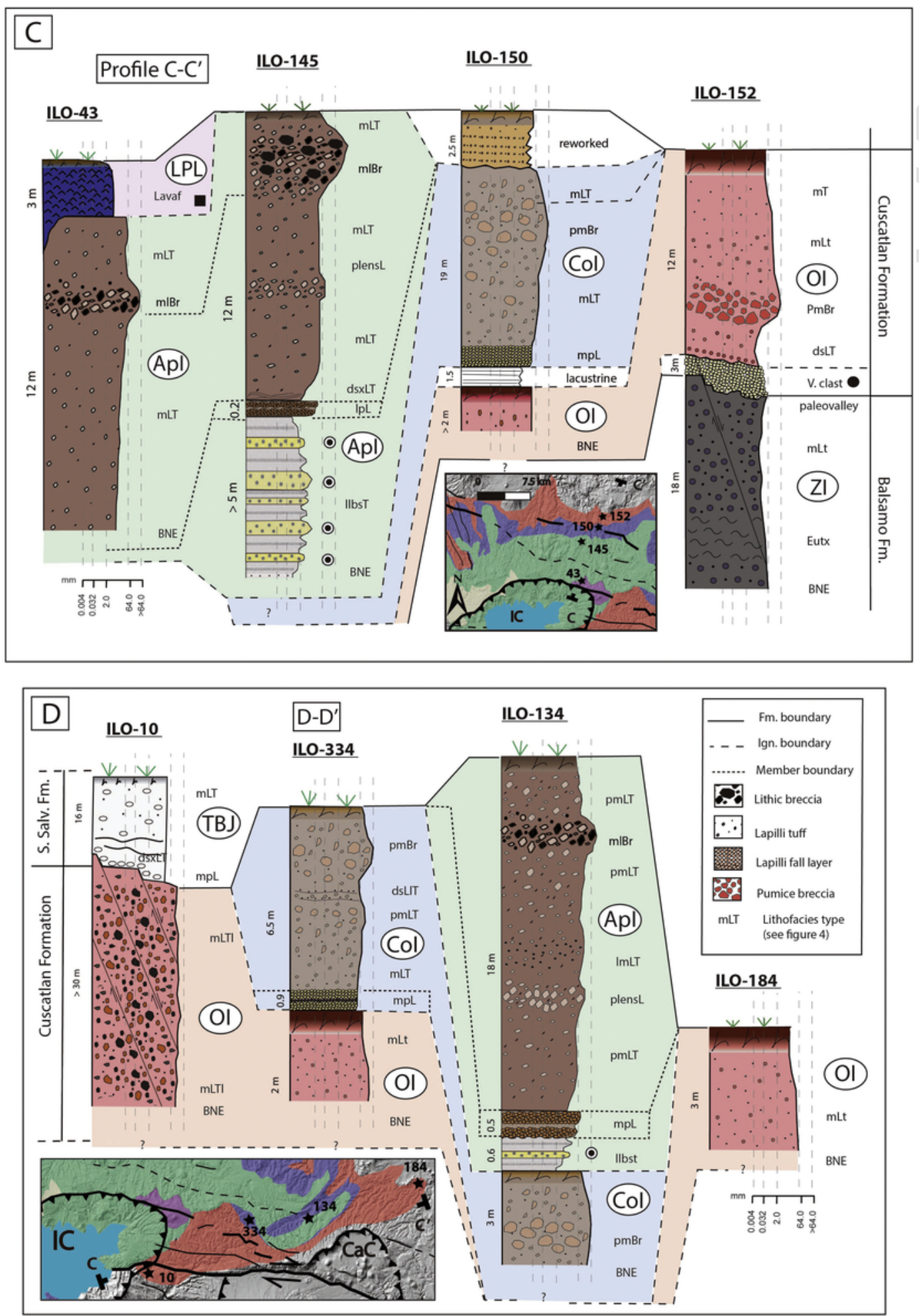

Fig. 12. (Continued)

The CoI is the result of the second large explosive eruption of IC. Similarly to OI, this eruption began with a brief eruptive column that formed a pumice fallout deposit of about $\sim 50 \mathrm{~cm}$ thick. The initial column was followed by PDCs erupted from the caldera as boiling-over, produced during the second collapse phase of IC. These PDCs moved over the surface filling the lower parts of the paleotopography at San Salvador Pull-Apart (Fig. 2). PDCs traveled in all directions from the caldera with high mobility. The CoI spread north as far as the Lempa River Water Reservoir, with a runout of about $40 \mathrm{~km}$ (ILO-82, Fig. 2). To the southwest CoI's PDCs reached La Libertad Port, at 
$26 \mathrm{~km}$ from the caldera (ILO-36, Fig. 2). This unit consists of a lithics-poor, non-welded ignimbrite, with zones of large-pumice breccia lenses and intrusive cognate blocks (Fig. 5c) that we interpret as pieces of the subcaldera magma chamber, which suggests changes in the magmatic mass rate and the break apart of the magma chamber wall during caldera collapse. Both high-particle concentrations in the PDCs and the long runout distances were maintained because of the continuous supply of dense currents at the vent (Roche et al., 2016).

The third eruption of the IC that formed the ApI started differently than the two previous ones. Instead of pumice fallout deposits, there is a sequence of dilute fine-ash PDC deposits with accretionary lapilli at the base of this ignimbrite, suggesting that the eruption started with a hydromagmatic phase. Magma-water interaction increases the explosivity (i.e., fragmentation), and the PDCs become more turbulent leaving local cross-bedded deposits (Brown et al., 2010). As the eruption continued, and once the ratio of water-magma in the system decreased, the eruption switched to magmatic style where a brief eruptive column was generated producing a layer of $40-50 \mathrm{~cm}$ of pumice fall deposit. This was followed by the eruption of sustained large-volume denser PDCs, which thickened the overall volume of the ApI. Throughout this quasi-steady sequence of dense PDCs, there is a horizon of coignimbritic lithic lag breccias observable in the proximity of IC, which includes lava lithics up to $50 \mathrm{~cm}$ in diameter probably indicating the third caldera collapse episode (Aguirre-Díaz and Labarthe-Hernández, 2003; ILO-145 and ILO-43, Figs. 2 and 12c). The top of ApI is locally slightly welded, due to the accumulation of hot pyroclastics along the valley where is located ILO-78/102 (Rank II-III, Quane and Russell, 2005; Fig. 12b).

Water driving the hydromagmatic eruptions of the ApI was probably derived from a paleolake that filled the Ilopango depression formed after the second caldera collapse at 1.56-1.34 Ma (during the CoI eruption), similarly to the Taal caldera lake eruption in Philippines at 1965 (Moore et al., 1966). In some cases, dilute PDCs generated by hydromagmatism can travel farther than denser PDCs, like in ApI, where the basal dilute surges are observable at the Lempa River Water Reservation shore and the denser PDC's did not (ILO-81 and 82; Figs. 2 and 12b). A similar scenario occurred at the NE of the caldera (ILO-327; Figs. 2 and 3), where dilute PDCs deposited $\sim 1 \mathrm{~m}$ of cross-stratified surges with no presence of massive and denser facies of ApI.

\subsection{Volumes and magnitudes of early explosive eruptions of the Ilopango caldera}

As the widespread distribution of the pyroclastic products of OI, $\mathrm{Col}$ and ApI indicates (Fig. 2), the first volcanic phases of IC were large-volume explosive eruptions, with OI being the largest reported so far, even larger than the TBJ (the last explosive eruption of IC with $39 \mathrm{~km}^{3}$ DRE; Dull et al., 2010). In order to characterize the magnitude and assess the minimum Volcanic Explosivity Index (VEI) of the three early IC eruptions, we estimated the deposit volumes of $\mathrm{OI}, \mathrm{CoI}$ and ApI. The volumes were calculated employing the Delaunay triangulation method (Macedonio and Pareschi, 1991), particularly suitable for the reconstruction of volume between geological horizons and about the interpolation of bivariate data, when function values are available at irregularly-spaced data points, like in our case. This method uses the area occupied by the tuff, the local thickness of several sites (sampling and data sites ILOs, Fig. 2), and the zero-thickness boundary points. All data were processed in an attribute table with ArcGIS 10.2 by ESRIC, following the method described in Pitcher et al. (2017). The estimated deposits volumes were then trans- formed into DRE volume using the density ranks table of Quane and Russell (2005).

The welding of OI favored better preservation of this deposit that allowed several data collection sites for OI volume estimation. In some sites either the base or the roof of the unit is missing (see table in Appendix D), so conservative estimations for the OI volume range from 78 to $64 \mathrm{~km}^{3}$ of PDC deposit and $\sim 50 \mathrm{~km}^{3}$ of DRE, indicating an eruption magnitude of 7.2 (Pyle, 2000) and a VEI 7 (Newhall and Self, 1982). These estimates do not include tephra fall deposits and the graben-caldera fill, which may be significant. If we assume a ratio of 1:1:1 of intracaldera ignimbrite, outflow ignimbrite and distal ash fall deposits, as proposed by Mason et al. (2004), the total volume would increase to $\sim 150 \mathrm{~km}^{3} \mathrm{DRE}$, reaching a VEI $>7$. In addition, the outflow sheets of OI probably reached the Pacific Ocean to the south as the smaller TBJ eruption did, and thus, an unknown amount of material, not-included in the volume estimates, may have gone out to sea. To the north, OI should have reached the Lempa River Water Reservoir area as CoI and ApI did (ILO-82; Fig. 2), since OI is much larger than the earlier eruptions deposit. The OI is presumably beneath these two younger ignimbrites and/or the recent lacustrine deposits in the distal zone. To the west, the PDCs of OI apparently traveled within an originally flat San Salvador Pull-Apart topography (Fig. 2), because at that period the San Salvador volcano did not exist as a topographic barrier (this volcano is $\sim 70 \mathrm{ka}$; Sofield, 2004). Therefore, we interpret that PDCs of this first explosive eruption traveled radially from the vent. Assuming the possible original distribution of OI (Fig. 13), this ignimbrite volume might increase to of $\sim 300 \mathrm{~km}^{3} \mathrm{DRE}$. This order of magnitude corresponds to a $\mathrm{VEI} \sim 8$, similar to the lower range of the supereruptions (Sparks et al., 2005; Self, 2006).

CoI and ApI outcrops showing complete thicknesses are scarce (table in Appendix D), and thus it was difficult to calculate an accurate volume of the second and third eruptions. Very conservative minimum volumes for these ignimbrites result in $16 \mathrm{~km}^{3}$ and $13 \mathrm{~km}^{3}$ of tephra respectively, and $>11 \mathrm{~km}^{3}$ and $9>\mathrm{km}^{3}$ as DRE. More realistic volume estimates would give volumes between the OI minimum volume $\left(\sim 50 \mathrm{~km}^{3} \mathrm{DRE}\right)$ and the TBJ volume $\left(39 \mathrm{~km}^{3}\right.$ DRE, Dull et al., 2010), because the deposit distributions of CoI and ApI are generally thicker and widespread than TBJ. For these reasons, the volume of these two eruptions should be higher than $40 \mathrm{~km}^{3}$ DRE (VEI $\geq 6$ ).

\subsection{Origin and geologic evolution of IC in relation with the regional tectonics}

The geodynamic evolution of the Ilopango area since 2 to 1 Ma includes the initial major volcanic explosive eruptions of IC (Fig. 13). These events began with the caldera collapse episodes associated with OI $(1.785 \pm 0.006 \mathrm{Ma}), \mathrm{CoI}(1.56 \pm 0.01 \mathrm{Ma})$ and ApI $(\sim 1.34 \mathrm{Ma})$. A key factor to be considered in the origin of these eruptions is the regional and local tectonics in Ilopango area. A schematic model of the volcano-tectonic evolution during the early explosive eruptions of IC is explained below and illustrated in Fig. 13:

1) The first major eruption, represented by the OI, lacks pre-ignimbrite thick pumice fallouts (Plinian) deposits, which is a characteristic of fissure ignimbrite-forming eruptions related to regional faults (e.g., Aguirre-Díaz and Labarthe-Hernández, 2003; Aguirre-Díaz et al., 2008) and corresponds to overpressure type caldera eruptions (Geyer and Martí, 2008). Close to the timing of the OI eruption $(1.785 \mathrm{Ma})$ there was an extensional setting within the ESFZ (Carr, 1976; Canora et al., 2014; Alonso-Henar et al., $2015,2017)$. This extension could have produced a graben at or near the site of the actual IC (Fig. 13a). At the same time, the extension favored the continued ascension of an elongate magma chamber 

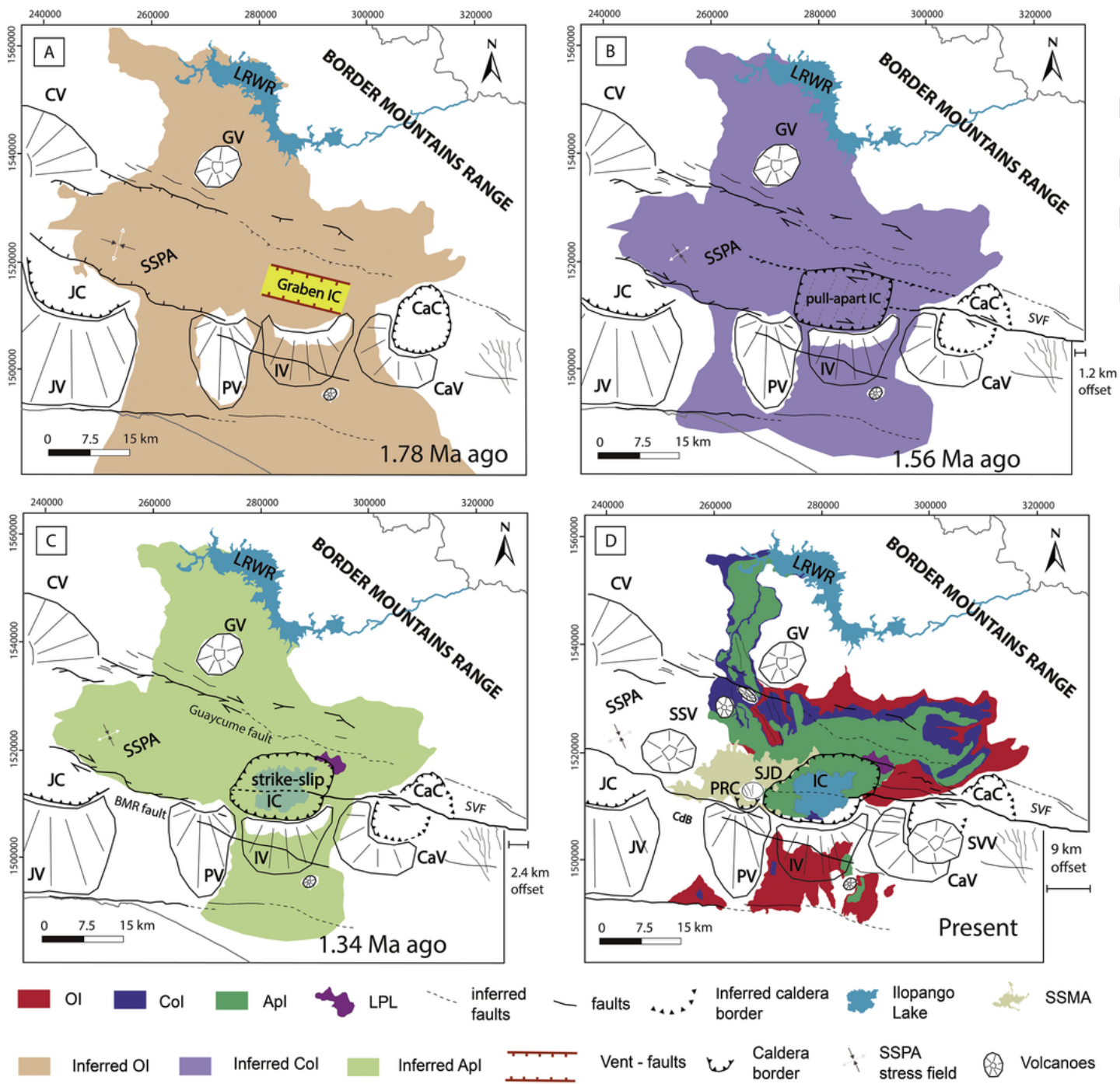

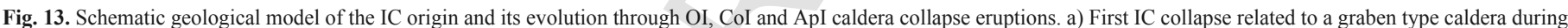

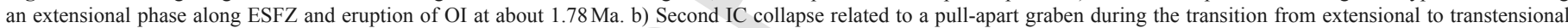

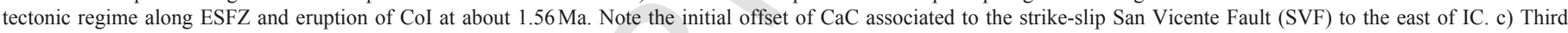

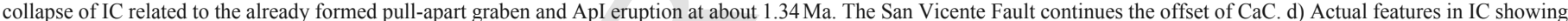
main faults and distribution of OI, CoI and ApI.

shallower levels (e.g., Aguirre-Díaz and Labarthe-Hernández, 2003; Costa and Marti, 2016) until the magmatic system suddenly opened along the graben's faults and the OI eruption occurred as fissure vents and producing the first IC collapse. This graben was capable of erupting massively the pumiceous pyroclastic currents that formed OI (the largest of the three ignimbrites reported here). Analogue models of Holohan et al. (2008) revealed a "graben localized above magma chamber" during an initial stage of extensional deformation in strike-slip calderas, the type of tectonic caldera that suggested Saxby et al. (2016) for the current IC.

2) During the timing among the first and the second explosive eruption of IC (a time span of 1.78 to $1.56 \mathrm{MaBP}$ ), the tectonic regime along the ESFZ changed gradually from extensional to transtensional, provoking the development of strike-slip faults and pull-apart structures along the El Salvador Volcanic Front (Correa-Mora et al., 2009; LaFemina et al., 2009; Alonso-Henar et al., 2015, 2017; Garibaldi et al., 2016). At the moment of CoI (the second eruption of IC at $\sim 1.56 \mathrm{MaBP}$ ), the San Vicente Fault already existed and it had displaced the Carbonera caldera rim with a dextral offset of $>1 \mathrm{~km}$ (CaC, Fig. 13b). Offset started at $\sim 1.70 \mathrm{MaBP}$ with an average slip rate of $\sim 5 \pm 0.5 \mathrm{~mm} / \mathrm{yr}$ (Canora et al., 2014; Rotolo and Castorina, 1998). This new input of laterally component in ESFZ could have changed the IC dynamics between the $\mathrm{OI}$ and $\mathrm{CoI}$ eruptions, evolving from a graben-caldera type to a pull-apart caldera type (Fig. 13a and b). Similar processes from extensional to transtensional settings in areas with calderas are the cases of the Suwoh, Ranau and Toba calderas along the Great Sumatran Fault Zone, in Indonesia (Bellier and Sébrier, 1994) and the calderas in the Sierra Madre Occidental, in Mexico (Aguirre-Díaz et al., 2008).

3) During the third explosive eruption of IC (ApI, at $\sim 1.34 \mathrm{MaBP}$ ) the resulting caldera was apparently affected by the strike-slip activity along the San Vicente Fault, which by then had already displaced the Carbonera caldera rim by $>2.3 \mathrm{~km}$ (Fig. 13c). Regionally, between the second and third caldera eruptions (time span of $1.56-1.34 \mathrm{Ma}$ ), the lateral component of the ESZF increases in detriment of the extensional (Canora et al., 2014; Alonso-Henar et al., 2015, 2017). The IC framework of a pull-apart caldera contin- 
ued during this eruption, but with a higher lateral component due to the effect of the San Vicente Fault prolongation westward (Fig. $13 \mathrm{~b}$ and $\mathrm{c})$. The presence of a coignimbritic lithic lag breccia within the ApI indicates that the third caldera collapse onset could have been in a setting of higher compression between blocks, caused probably by lateral stretching (Holohan et al., 2008). Calderas in strike-slip zones are often elongated by the regional faulting control, and apparently formed from noncircular but rather elongated magmatic reservoirs, for example the Rannoch Moor granite in Scotland (Jacques and Reavy, 1994), or the Ardara pluton, Ireland (Molyneux and Hutton, 2000). These complexes were deformed and elongated by transtensive regional faults prior to full crystallization. This kind of stretching that increase compression locally is currently occurring in IC area (Garibaldi et al., 2016), where recent gravimetric studies classified it as a strike-slip caldera (Saxby et al., 2016; Fig. 13d).

As with the possible proto-graben related to the OI eruption, there is no clear geomorphologic evidence that IC was a pull-apart caldera type during the $\mathrm{CoI}$ and ApI eruptions. However, it is possible that this old pull-apart basin is being cut by the strike-slip San Vicente Fault. In general, the obliteration of a pull-apart/graben appears to be the consequence of the new strike-slip faulting that develops and propagates across the pre-basin through its center (e.g., Bellier and Sébrier, 1994). An important consequence of this type of tectonic evolution is that pull-apart grabens could be ephemeral structures within strike-slip faults (Holohan et al., 2008).

The potential volumes reported here for the three early caldera collapse eruptions make IC the largest active eruptive center of the El Salvador Volcanic Front since about 1.75 Ma. A high magma production was necessary to generate these amounts of pyroclastic products of the early IC's stages. The primary control for the production of great amounts of silicic magma at continental-margin systems is the flux of basaltic magma from the mantle (Smith, 1979; Hildreth, 1981; de Silva and Gosnold, 2007). This high flux of magma in the CAVA was apparently possible during the rollback of the subducted plate of Cocos beneath Central America since the late Miocene (Alonso-Henar et al., 2015, 2017), which may have caused the opening of a mantle wedge and the consequent process of flare-up (Aguirre-Díaz et al., 2008). Continued rise of magma to shallow levels was favored by the extensional and transtensional tectonics, where the regional strike-slip faults and local pull-apart basins worked out as the principal magma pathways.

\section{Conclusions}

The Ilopango caldera (IC) had multiple caldera collapse eruptions during its eruptive history. The first three caldera-forming eruptions from Ilopango produced the OI at $1.785 \pm 0.006 \mathrm{Ma}$, the $\mathrm{CoI}$ at $1.56 \pm 0.01 \mathrm{Ma}$, and the ApI at $\sim 1.34 \mathrm{Ma}$. They all are rhyolitic and calcalkaline tuffs, which is common for magmas at continental margins subduction zones, such as the Central American Volcanic Arc. OI was the largest eruption of Ilopango caldera complex, probably generated from a graben-type caldera related to the extensional tectonics at central El Salvador. This deposit covered an area of $\sim 3000 \mathrm{~km}^{2}$ with a minimum DRE volume of $50 \mathrm{~km}^{3}$, likely up to $300 \mathrm{~km}^{3}$ DRE considering the coignimbritic ash cloud, the intracaldera fill and eroded deposits, corresponding to a VEI $\geq 7$. Both the CoI and ApI have smaller volumes than OI, but similar or even larger than TBJ deposit, which is more than $\sim 40 \mathrm{~km}^{3}$ DRE. We suggest that the caldera structure changed from pure extensional graben during the OI eruption to a pull-apart during the CoI and ApI eruptions, with higher lateral component for the last one. All three caldera-forming episodes are related to the evolution of the ESFZ, which actually involves large strike-slip faults and pull-apart basins. Ilopango caldera complex represents the largest, highly explosive, and active long-lived caldera structure in El Salvador. Activity related to ignimbrite-forming eruptions at Ilopango started at $1.785 \mathrm{MaBP}$ and it is still producing large ignimbrites sheets like the TBJ, emplaced $\sim 1500$ years ago.

\section{Uncited references}

Ferrari et al., 2002

Koppers et al., 2003

Min et al., 2000

Steiger and Jäger, 1977

Taylor, 1977

York, 1969

\section{Acknowledgements}

This study was financed by CONACYT-CB grant 240447 to GAD. We appreciate the logistical support of the Ministerio de Medio Ambiente y Recursos Naturales - MARN, and of the Policia Nacional Civil - PNC, of El Salvador. We thank the doctoral scholarship grant to the first author from CONACYT-Mexico. We want to be grateful to Juan Vazquez for thin section elaboration, to Lozano Santacruz and Patricia Girón for XRF analyses, Ofelia Perez for the REE and trace elements analyses, and Alex Iriondo for SEM and petrographic analyses. We acknowledge to Anthony Koppers for his help and support in the $\mathrm{Ar} / \mathrm{Ar}$ geochronology laboratory at Oregon State University (OSU). This manuscript was greatly improved by comments and suggestions from the editor Joan Martí and the reviewers Valerio Acocella and Jim Cole.

\section{Appendix A. Supplementary data}

Supplementary data to this article can be found online at https:// doi.org/10.1016/j.jvolgeores.2018.12.004.

\section{References}

Acocella, V., 2007. Understanding caldera structure and development: an overview of analogue models compared to natural calderas. Earth-Sci. Rev. 85, 125-160.

Acocella, V., Korme, T., Salvini, F., Funiciello, R., 2002. Elliptic calderas in the Ethiopian Rift: control of pre-existing structures. J. Volcanol. Geotherm. Res. 119, 189-203. https://doi.org/10.1016/S0377-0273(02)00342-6.

Agostini, S., Corti, G., Doglioni, C., Carminati, E., Innocenti, F., Tonarini, S., Manetti, P., Di Vincenzo, G., Montanari, D., 2006. Tectonic and magmatic evolution of the active volcanic front in El Salvador: insight into the Berlín and Ahuachapán geothermal areas. Geothermics 35, 368-408. https://doi.org/10.1016/j.geothermics. 2006.05.003.

Aguirre-Díaz, G.J., Labarthe-Hernández, G., 2003. Fissure ignimbrites: fissure source origin for voluminous ignimbrites of the Sierra Madre Occidental and its relationship with Basin and Range faulting. Geology 31, 773-776.

Aguirre-Díaz, G.J., Martí, J., 2015. Graben calderas: examples from Mexico, Central America, and the Andes. In: 26th IUGG General Assembly, Prague, Czech Republic, June 22-July 2, 2015; Abstracts. https://www.czech-in.org/cm/IUGG/CM. NET.WebUI/CM.NET.WEBUI.scpr/SCPRfunctiondetail. aspx?confID $=05000000-0000-0000-0000-000000000053 \&$ sesID $=05000000-0000-0000-0000-000000002536 \&$ absID $=07000000-0000-0000-0000-000000022205$.

Aguirre-Díaz, G.J., Labarthe-Hernández, G., Tristán-González, M., Nieto-Obregón, J., Gutiérrez-Palomares, I., 2008. Ignimbrite flare-up and graben-calderas of the Sierra Madre Occidental, Mexico. In: Gottsmann, J., Martí, J. (Eds.), Caldera Volcanism: Analysis, Modelling and Response. Developments in Volcanology, vol. 10, Elsevier, Amsterdam. ISBN: 978-0-444-53165-0https://doi.org/10.1016/ S1871-644X(07)00004-6, (492 pp., (143-180 pp.)).

Aguirre-Díaz, J.G., Suñe-Puchol, I., Davila-Harris, P., Pedrazzi, D., Hernandez, W., Gutierrez, E., 2017. Volcanic history of the Ilopango caldera, Central American Volcanic Arc. In: 113th Annual Meeting, 2017 GSA Cordilleran Section, Hawaii, USA. 
Alonso-Henar, J., Schreurs, G., Martinez-Díaz, J.J., Álvarez-Gõmez, J.A., Villamor, P., 2015. Neotectonic development of the El Salvador Fault Zone and implications for deformation in the Central America Volcanic Arc: insights from 4-D analog modeling experiments. Tectonics 34, 133-151. https://doi.org/10.1002/ 2014 TC003723.

Alonso-Henar, J., Álvarez-Gõmez, J.A., Martinez-Díaz, J.J., 2017. Neogene-quaternary evolution from transpressional to transtesional tectonics in Northern Central America controlled by cocos: Caribbean subduction coupling change. J. Iber. Geol. https://doi.org/10.1006/s415113-017-0034-2.

Alvarado, D., DeMets, C., Tikoff, B., Hernandez, D., Wawrzyniec, T.F., Pullinger, C., Mattioli, G., Turner, H.L., Rodriguez, M., Correa-Mora, F., 2011. Forearc motion and deformation between El Salvador and Nicaragua: GPS, seismic, structural, and paleomagnetic observations. Lithosphere 3, 3-21. https://doi.org/10.1130/L108.1.

Alvarenga, E.R., Hernández, D.A., Hernández-Flores, D.A., 2001. Cronología de sismos destructivos en El Salvador: Servicio Geológico Nacional, Área de Sismología.

Arculus, R.J., Curran, E.B., 1972. The genesis of the calc-alkaline rock suite. Earth Planet. Sci. Lett. 15, 255-262.

Authemayou, C., Brocard, G., Teyssier, C., Simon-Labric, T., Guttiérrez, A., Chiquín, E.N., Morn, S., 2011. The Caribbean-North America-Cocos Triple Junction and the dynamics of the Polochic-Motagua fault systems: pull-up and zipper models. Tectonics 30, 1-23. https://doi.org/10.1029/2010TC002814.

Bacon, C.R., Lanphere, M.A., 2006. Eruptive history and geochronology of Mount Mazama and the Crater Lake region, Oregon. Geol. Soc. Am. Bull. 118, 1331-1359. https://doi.org/10.1130/B25906.1

Bellier, O., Sébrier, M., 1994. Relationship between tectonism and volcanism along the Great Sumatran Fault Zone deduced by spot image analyses. Tectonophysics 233, 215-231. https://doi.org/10.1016/0040-1951(94)90242-9.

Bernal, J.P., Lozano-Santacruz, R., 2005. Characterization of a new set of eight geochemical reference materials for XRF major and trace element analysis. Rev. Mex. Cienc. Geol. 22 (3), 329-344.

Branney, M.J., Kokelaar, P., 1997. Giant bed from a sustained catastrophic density current flowing over topography: Acatlán ignimbrite, Mexico. Geology 25, 115-118. https://doi.org/10.1130/0091-7613(1997)025<0115:GBFASC >2.3.CO;2.

Branney, M.J., Kokelaar, P., 2002. Pyroclastic density currents and the sedimentation of ignimbrites. Geol. Soc. Lond. Mem. 27, (152 pp.).

Brown, R.J., Branney, M.J., Maher, C., Dávila-Harris, P., 2010. Origin of accretionary lapilli within ground-hugging density currents: evidence from pyroclastic couplets on Tenerife. Bull. Geol. Soc. Am. 122, 305-320. https://doi.org/10.1130/B26449. 1.

Canora, C., Villamor, P., Martínez-Díaz, J.J., Berryman, K.R., Álvarez-Gómez, J.A., Capote, R., Hernández, W., 2012. Paleoseismic analysis of the San Vicente segment of the El Salvador Fault Zone, El Salvador, Central America. Geol. Acta 10, 103-123. https://doi.org/10.1344/105.000001700.

Canora, C., Martínez-Díaz, J.J., Villamor, P., Staller, A., Berryman, K., Álvarez-Gómez, J.A., Capote, R., Diaz, M., 2014. Structural evolution of the El Salvador Fault Zone: an evolving fault system within a volcanic arc. J. Iber. Geol. 40, 471-488.

Carr, M.J., 1976. Underthrusting and Quaternary faulting in northern Central America Geol. Soc. Am. Bull. 87, 825-829. https://doi.org/10.1130/ 0016-7606(1976)87<825:UAQFIN $>2.0 . \mathrm{CO} ; 2$.

Carr, M., Patiño, L., Feingenson, M., 2007. Chapter 22: petrology and geochemistry of lavas. In: Cent. Am. Geol. Resour. Hazards. pp. 1-26.

CEL (Comision Ejecutiva Hidroelectrica del Rio Lempa), 1992. Desarrollo de los Recursos Geotermicos del Area Centro-Occidental de El Salvador. Prefactibilidad Geotermica del Area de Coatepeque. In: Reconocimiento Geotermico. Informe Final. Internal Report.

Cole, J.W., Milner, D.M., Spinks, K.D., 2005. Calderas and caldera structures: a review. Earth-Sci. Rev. 69, 1-96.

Correa-Mora, F., DeMets, C., Alvarado, D., Turner, H.L., Mattioli, G., Hernandez, D. Pullinger, C., Rodriguez, M., Tenorio, C., 2009. GPS-derived coupling estimates for the Central America subduction zone and volcanic arc faults: El Salvador, Honduras and Nicaragua. Geophys. J. Int. 179, 1279-1291.

Corti, G., Carminati, E., Mazzarini, F., Garcia, M.O., 2005. Active strike-slip faulting in El Salvador, Central America. Geology 33, 989-992.

Costa, A., Marti, J., 2016. Stress field control during large caldera-forming eruptions. Front. Earth Sci. 4, 92. https://doi.org/10.3389/feart.2016.00092.

Costa, A., Gottsmann, J., Melnik, O., Sparks, R.S.J., 2011. A stress-controlled mechanism for the intensity of very large magnitude explosive eruptions. Earth Planet. Sci. Lett. 310, 161-166. https://doi.org/10.1016/j.epsl.2011.07.024.

Costa, A., Smith, V., Macedonio, G., Matthews, N., 2014. The magnitude and impact of the Youngest Toba Tuff super-eruption. Front. Earth Sci. 2, 16. https://doi.org/ 10.3389 /feart.2014.00016.

DeMets, C., 2001. A new estimate for present-day Cocos-Caribbean plate motion: Implications for slip along the Central American volcanic arc. Geophys. Res. Lett. 28, 4043-4046. https://doi.org/10.1029/2001GL013518.
Dixon, T.H., 1993. GPS measurement of relative motion of the Cocos and Caribbean plates and strain accumulation across the Middle America Trench. Geophys. Res. Lett. 20, 2167-2170. https://doi.org/10.1029/93GL02415.

Donnelly, T.W., Horne, G.S., Finch, R.C., Lopez-Ramos, E., 1990. Northern Central America: the Maya and Chortis blacks. In: Dengo, G., Case, J.E. (Eds.), The Geology of North America: The Caribbean Region. pp. 37-76.

Druitt, T.H., Sparks, R.S.J., 1984. On the formation of calderas during ignimbrite eruptions. Nature 310, 679-681.

Dull, R.A., Southon, J.R., Sheets, P., 2001. Volcanism, ecology and culture: a reassessment of the Voclán Ilopango TBJ eruption in the southern Maya realm. Lat. Am. Antiq. 12 (1), 25-44

Dull, R.A., Southon, J.R., Kutterolf, S., Freundt, A., Wahl, D., Sheets, P., 2010. Did the TBJ Ilopango eruption cause the AD 536 event?. In: AGU Fall Meet. Abstr.. vol. 1, p. 2370.

Francis, P.W., O'Callaghan, L., Kretzschmar, G.A., Thorpe, R.S., Sparks, R.S.J., Page, R.N., 1983. The Cerro Galan ignimbrite. Nature 301, 51-53.

Funk, J., Mann, P., McIntosh, K., Stephens, J., 2009. Cenozoic tectonics of the Nicaraguan depression, Nicaragua, and Median Trough, El Salvador, based on seismic-reflection profiling and remote-sensing data. Bull. Geol. Soc. Am. 121, 1491-1521. https://doi.org/10.1130/B26428.1.

Garibaldi, N., Tikoff, B., Hernández, W., 2016. Neotectonic deformation within an extensional stepover in El Salvador magmatic arc, Central America: implication for the interaction of arc magmatism and deformation. Tectonophysics 693, 327-339. https://doi.org/10.1016/j.tecto.2016.05.015.

Geyer, A., Martí, J., 2008. The new worldwide collapse caldera database (CCDB): a tool for studying and understanding caldera processes. J. Volcanol. Geotherm. Res. 175, 334-354. https://doi.org/10.1016/j.jvolgeores.2008.03.017.

Girard, G., van Wyk de Vries, B., 2005. The Managua Graben and Las Sierras-Masaya volcanic complex (Nicaragua); pull-apart localization by an intrusive complex: results from analogue modeling. J. Volcanol. Geotherm. Res. 144, 37-57. https://doi. org/10.1016/j.jvolgeores.2004.11.016.

Golombek, M.P., Carr, M.J., 1978. Tidal triggering of seismic and volcanic phenomena during the 1879-1880 eruption of Islas Quemadas volcano in El Salvador, Central America. J. Volcanol. Geotherm. Res. 3, 299-307. https://doi.org/10.1016/ 0377-0273(78)90040-9.

Gottsmann, J., Martí, J., 2008. Caldera volcanism: analysis, modelling and response. In: Developments in Volcanology. vol. 10, Elsevier, Amsterdam, (492 pp.).

Gottsmann, J., Lavallée, Y., Martí, J., Aguirre-Díaz, G., 2009. Magma-tectonic interaction and the eruption of silicic batholiths. Earth Planet. Sci. Lett. ISSN 0012-821X, 284, 426-434. https://doi.org/10.1016/j.epsl.2009.05.008.

Guzmán-Speziale, M., Valdés-González, C., Molina, E., Gómez, J.M., 2005. Seismic activity along the Central America volcanic arc: is it related to subduction of the Cocos plate?. Tectonophysics 400, 241-254. https://doi.org/10.1016/j.tecto.2005 03.006 .

Hernández, E.W., 2004. Características geotécnicas y vulcanológicas de las tefras de Tierra Blanca Joven de Ilopango, El Salvador (Tesis de maestría). Univ. Politécnica de El Salvador, San Salvador, (115 pp.).

Hernández, W., 2008. Aspectos geológicos que influyen en las aguas subterráneas y en la respuesta sísmica del Area Metropolitana de San Salvador. In: Revista ASIA No. 162, (29-41 pp.)

Hernández, E.W., Ferrés, D., Delgado-Granados, H., Pullinger, C., Gutiérrez de Henríquez, E., 2010. The last 40 ka eruptive cycle of Ilopango caldera deposits: a settlement for the San Salvador Metropolitan Area (El Salvador). In: Abstract Volume, International Conference Cities on Volcanoes. Fundación Canaria ITER, Tenerife, p. 56.

Hildreth, E.W., 1981. Gradients in silicic magma chambers: implications for lithospheric magmatism. J. Geophys. Res. 86, 10,153-10,192. https://doi.org/10.1029/ JB086iB11p10153.

Holohan, E.P., Van Wyk de Vries, B., Troll, V.R., 2008. Analogue models of caldera collapse in strike-slip tectonic regimes. Bull. Volcanol. 70, 773-796. https://doi. org/10.1007/s00445-007-0166-x.

Hutton, D.H.W., Reavy, R.J., 1992. Strike-slip tectonics and granite petrogenesis. Tectonics $11,960-967$.

Jacques, J.M., Reavy, R.J., 1994. Caledonian plutonism and major lineaments in the SW Scottish Highlands. J. Geol. Soc. Lond. 151, 955-969.

Koppers, A.A.P., 2002. ArArCALC—-software for 40Ar/39Ar age calculations. Com$J R$ put. Geosci. 28 (5), 605-619. https://doi.org/10.1016/S0098-3004(01)00095-4.

Koppers, A.A.P., Gowen, M.D., Colwell, L.E., Gee, J.S., Lonsdale, P.F., Mahoney, J.J., Duncan, R.A., 2011. New 40Ar/39Ar age progression for the Louisville hot spot trail and implications for inter-hot spot motion. Geochem. Geophys. Geosyst. 12, Q0AM02https://doi.org/10.1029/2011GC003804.

Kuiper, K.F., Deino, A., Hilgen, F.J., Krijgsman, W., Renne, P.R., Wijbrans, J.R., 2008. Synchronizing rock clocks of Earth history. Science 320, 500-504. https:// doi.org/10.1126/science.1154339.

Kutterolf, S., Freundt, A., Schacht, U., Bürk, D., Harders, R., Mörz, T., Peréz, W., 2008. Pacific offshore record of plinian arc volcanism in Central America: 3. 
Application to forearc geology. Geochem. Geophys. Geosyst. 9, https://doi.org/10 1029/2007GC001826.

LaFemina, P., Dixon, T.H., Govers, R., Norabuena, E., Turner, H., Saballos, A., Mattioli, G., Protti, M., Strauch, W., 2009. Fore-arc motion and Cocos Ridge collision in Central America. Geochem. Geophys. Geosyst. 10, https://doi.org/10.1029/ 2008 GC002181.

LeBas, et al., 1986. A chemical classification of volcanic rocks based on the total alkali-silica diagram. J. Petrol. 27, 745-750.

Lexa, J., Šebesta, J., Chavez, J.A., Hernández, W., Pécskay, Z., 2011. Geology and volcanic evolution in the southern part of the San Salvador Metropolitan Area. J. Geosci. 56, 105-140. https://doi.org/10.3190/jgeosci.088.

Lipman, P.W., 1997. Subsidence of ash-flow calderas: relation to caldera size and magma-chamber geometry. Bull. Volcanol. 59, 198-218. https://doi.org/10.1007/ s004450050186.

Lipman, P.W., 2000. Calderas. In: Sigurdsson, H. (Ed.), Encyclopedia of Volcanoes. Academic Press, San Francisco, pp. 643-662.

Lipman, P.W., Dungan, M.A., Brown, L.L., Deino, A., 1996. Recurrent eruption and subsidence at the Platoro caldera complex, southeastern San Juan volcanic field, Colorado: new tales from old tuffs. Bull. Geol. Soc. Am. 108, 1039-1055. https:// doi.org/10.1130/0016-7606(1996)108<1039:REASAT>2.3.CO;2.

Ludwig, K., 2008. Manual for isoplot 3.7. In: Berkeley Geochronology Center, Special Publication 4. p. 77, (rev.)

Macedonio, G., Pareschi, M.T., 1991. An algorithm for the triangulation of arbitrarily distributed points: applications to volume estimate and terrain fitting. Comput. Geosci. 17, 859-874. https://doi.org/10.1016/0098-3004(91)90086-S.

Mann, P., 2007. Overview of the tectonic history of northern Central America. In: Mann, P. (Ed.), Geologic and Tectonic Development of the Caribbean Plate Boundary in Northern Central America. Geological Society of America Special Papers, vol. 428, pp. 1-19.

Marti, J., Diez-Gil, J.L., Ortiz, R., 1991. Conduction model for the thermal influence of lithic clasts in mixtures of hot gases and ejecta. J. Geophys. Res. 96 (B13), (Pages $21,879.21,885)$.

Marti, J., Ablay, G.J., Redshaw, L.T., Sparks, R.S.J., 1994. Experimental studies of collapse calderas. J. Geol. Soc. Lond. 151, 919-929.

Martínez-Díaz, J.J., Álvarez-Gómez, J.A., Benito, B., Hernández, D., 2004. Triggering of destructive earthquakes in El Salvador. Geology 32, 65-68. https://doi.org/10. $1130 / \mathrm{G} 20089.1$

P.R., K.R.

Molina, F., Martí, J., Aguirre, G., Vega, E., Chavarría, L., 2014. Stratigraphy and structure of the Cañas Dulces caldera (Costa Rica). Bull. Geol. Soc. Am. 126, 1465-1480. https://doi.org/10.1130/B31012.1.

Molyneux, S.J., Hutton, D.H.W., 2000. Evidence for significant granite space creation by the ballooning mechanism; the example of the Ardara Pluton, Ireland. Geol. Soc. Am. Bull. 112, 1543-1558.

Montero, W., Dewey, J., 1982. Shallow-focus seismicity, composite focal mechanisms, and tectonics of the Valle Central of Costa Rica. Bull. Seismol. Soc. Am. 72, $1611-1626$

Moore, J.G., Nakamura, K., Alcaraz, A., 1966. The 1965 eruption of Taal volcano. Science 151, 955-960.

Morris, J.D., Ryan, J.G., 2004. Subduction zone processes and implications for changing composition of the upper and lower mantle. In: Holland, H.D., Turekian, K.K. (Eds.), Treatise on Geochemistry. Elsevier-Pergamon, Oxford, pp. 451-470.

Murphy, J.B., 2007. Igneous rock associations 8. Arc magmatism II: geochemical and isotopic characteristics. Geosci. Can. 34, 1.

Newhall, C.G., Dzurisin, D., 1988. Historical Unrest at Large Calderas of the World. U.S. Geological Survey, (1109 pp.).

Newhall, C.G., Self, S., 1982. The volcanic explosivity index (VEI) an estimate of explosive magnitude for historical volcanism. J. Geophys. Res. Oceans 87, 1231-1238. https://doi.org/10.1029/JC087iC02p01231.

Ortega-Obregón, C., Solari, L., Gómez-Tuena, A., Elías-Herrera, M., Ortega-Gutiérrez, F., Macías-Romo, C., 2013. Permian-Carboniferous arc magmatism in southern Mexico: $\mathrm{U}-\mathrm{Pb}$ dating, trace element and $\mathrm{Hf}$ isotopic evidence on zircons of earliest subduction beneath the western margin of Gondwana. Int. J. Earth Sci. 103 (5), 1287-1300. https://doi.org/10.1007/s00531-013-0933-1.

Pacheco-Hoyos, J.G., Aguirre-Díaz, G.J., Dávila-Harris, P., 2018. Boiling-over dense pyroclastic density currents during the formation of the $\sim 100 \mathrm{~km}^{3}$ Huichapan ignimbrite in Central Mexico: stratigraphic and lithofacies analysis. J. Volcanol. Geotherm. Res. 349, 268-282.

Peccerillo, A., Taylor, S.R., 1976. Geochemistry of Eocene calcalkaline volcanic rocks from the Kastamonu area, Northern Turkey. Contrib. Mineral. Petrol. 58, 63-81.

Pedrazzi, D., Sunyé-Puchol, I., Aguirre-Díaz, G.J., Costa, A., Davila-Harris, P., Hernández, W., Gutierrez, E., 2018. The Ilopango Tierra Blanca Joven (TBJ) eruption, El Salvador: volcano-stratigraphy of a major Holocene event of Central America and hazards implications EGU General Assembly 2018. In: EGU2018-8455. vol. 20.

Pitcher, B.W., Kent, A.J.R., Grunder, A.L., Duncan, R.A., 2017. Frequency and volumes of ignimbrite eruptions following the Late Neogene initiation of the
Central Oregon High Cascades. J. Volcanol. Geotherm. Res. 339, 1-22. https://doi. org/10.1016/j.jvolgeores.2017.04.019.

Pyle, D.M., 2000. Sizes of volcanic eruptions. In: Sigurdsson, H., et al. (Eds.), Encyclopedia of Volcanoes. Academic Press, pp. 263-269.

Quane, S.L., Russell, J.K., 2005. Ranking welding intensity in pyroclastic deposits. Bull. Volcanol. 67, 129-143. https://doi.org/10.1007/s00445-004-0367-5.

Rampino, M.R., Self, S., 1993. Climate-volcanism feedback and the Toba eruption of $\sim 74,000$ years ago. Quat. Res. https://doi.org/10.1006/qres.1993.1081.

Reynolds, J.H., 1987. Timing and sources of Neogene and Quaternary volcanism in south-central Guatemala. J. Volcanol. Geotherm. Res. 33, 9-22.

Richer, M., Mann, C.P., Stix, J., 2004. Mafic magma injection triggers eruption at Ilopango Caldera, El Salvador, Central America. In: Spec. Pap. 375 Nat. Hazards El Salvador. pp. 175-190. https://doi.org/10.1130/0-8137-2375-2.175.

Robertson, E.A.M., Biggs, J., Cashman, K.V., 2015. Influence of Regional Tectonics and Pre-existing Structures on the Formation of Elliptical Calderas in the Kenyan Rift School of Earth Sciences. University of Bristol, Wills Memorial Building, British Geological Survey, Murchison House, West Mains Road, Edinburgh EH9 3LA, UK.

Roche, O., Buesch, D.C., Valentine, G.A., 2016. Slow-moving and far-travelled dense pyroclastic flows during the Peach Spring super-eruption. Nat. Commun. 7, 10890

Rose, W.I., Conway, F.M., Pullinger, C.R., Deino, A., McIntosh, K., 1999. An improved age framework for late Quaternary silicic eruptions in northern Central America. Bull. Volcanol. 61, 106-120. https://doi.org/10.1007/s004450050266.

Rotolo, S.G., Castorina, F., 1998. Transition from mildly-tholeiitic to calc-alkaline suite: the case of Chichontepec volcanic centre, El Salvador, Central America. J. Volcanol. Geotherm. Res. 86, 117-136. https://doi.org/10.1016/ S0377-0273(98)00076-6.

Sánchez-Esquivel, I.A., 2016. Levantamiento batimétrico y medición de parámetros físico-químicos en el Lago de Ilopango, El Salvador, (Bachelor Thesis at Facultad de Ciencias Naturales y Matemática, Escuela de Física, Universidad de El Salvador, El Salvador).

Saxby, J., Gottsmann, J., Cashman, K., Gutiérrez, E., 2016. Magma storage in a strike-slip caldera. Nat. Commun. 7, 12295. https://doi.org/10.1038/ ncomms 12295.

Self, S., 2006. The effects and consequences of very large explosive volcánic eruptions. Phil. Trans. R. Soc. A 364, 2073-2097. https://doi.org/10.1098/rsta.2006. 1814.

de Silva, S.L., Gosnold, W.A., 2007. Episodic construction of batholiths: insights from the spatiotemporal development of an ignimbrite flare-up. J. Volcanol. Geotherm. Res. 167, 320-335. https://doi.org/10.1016/j.jvolgeores.2007.07.015.

Simkin, T., Siebert, L., 1994. Volcanoes of the World, 2nd ed. Geoscience Press, Tucson.

Sitemap, H.H., Articles, F.S., Union, A.G., 2014. The Smithsonian/NASA Astrophysics Data System Miocene Zircon Crystals in Dacite From Ilopango Caldera, El Salvador: Evidence for Recycling of Plutonic Rocks. 8-9.

Smith, R.L., 1979. Ash-flow magmatism. In: Geological Society of America Special Paper 1749, vol. 180, pp. 5-27

Smith, R.L., Bailey, R.A., 1968. Resurgent caldrons. Mem. Geol. Soc. Am. 116, 613-662.

Smith, R.B., Braile, L.W., 1994. The Yellowstone hotspot. J. Volcanol. Geotherm. Res. 61, 121-187.

Sofield, D., 2004. Eruptive history and volcanic hazards of Volcan San Salvador. Geol. Soc. Am. Spec. Pap. 375, 147-158.

Solari, L.A., Gómez-Tuena, A., Bernal, J.P., Pérez-Arvízu, O., Tanner, M., 2010. U-Pb zircon geochronology with an integrated LA-ICP-MS microanalytical workstation: achievements in precision and accuracy. Geostand. Geoanal. Res. 34, 5-18.

Sparks, R.S.J., Francis, P.W., Hamer, R.D., Pankhurst, R.J., O'Callaghan, L.O., Thorpe, R.S., Page, R., 1985. Ignimbrite of the Cerro Galan Caldera, NW Argentina. J. Volcanol. Geotherm. Res. 24, 205-248. https://doi.org/10.1016/ 0377-0273(85)90071-X.

Sparks, S., Self, S., Grattan, J.P., Oppenheimer, C., Pyle, D., Rymer, H., 2005. Supereruptions: global effects and future threats. In: Report of a Geological Society of London Working Group. The Geological Society, London, (24 pp.).

Staller, A., Martínez-Díaz, J.J., Benito, B., Alonso-Henar, J., Hernández, D. Hernández-Rey, R., Díaz, M., 2016. Tectonophysics Present-day crustal deformation along the El Salvador Fault Zone from ZFESNet GPS network. Tectonophysics 670, 66-81. https://doi.org/10.1016/j.tecto.2015.12.017.

R.H.,

Sun, S.S., McDonough, W.F., 1989. Chemical and isotopic systematics of oceanic basalts: implications for mantle composition and processes. In: Saunders, A.D. Norry, M.J. (Eds.), Magmatism in the Oceanic Basins. Geological Society of London Special Publication, vol. 42, pp. 313-345.

Sunye-Puchol, I., Aguirre-Díaz, G.J., Davila-Harris, P., Pedrazzi, D., Gutierrez, E., Hernanez, W., Miggins, D., Costa, A., 2017. The voluminous 1.5 Ma Olocuilta Ignimbrite: a pre-colapse fissure supereruption of Ilopango caldera, El Salvador. In: J.R.. , 
Tikoff, B., de Saint Blanquat, 1997. Transpressional shearing and strike-slip partitioning in the Late Cretaceous Sierra Nevada magmatic arc, California. Tectonics 16, $442-459$.

Turner, H.L., La Femina, P., Saballos, A., Mattioli, G., Jansma, P., Dixon, T., 2007. Kinematics of the Nicaraguan forearc from GPS geodesy. Geophys. Res. Lett. 34, (5 pp.).

Weber H. S., Wiesemann G., Wittek indt H., 1974. Mapa Geológico de la República de El Salvador/Geologische Übersichtskarte der Republik El Salvador 1: 500,000 (after geological maps 1:100000 - 1967-74) Bundesanstalt für Geowissenschaften und Rohstoffe, Hannover; Bundesanstalt für Bodenforschung, Hannover.
Weinberg, R.E., 1992. Neotectonic development of western Nicaragua. Tectonics 11 (5), 1010-1017.

Weyl, R., 1957. Las Tobas Fundidas de la Cadena Costera. 5551, Universidad de Kiel, Alemania, DC, 2.

Williams, H., Meyer-Abich, H., 1955. Volcanism in the southern part of El Salvador, with particular reference to the collapse basins of Lakes Coatepeque and Ilopango. In: Univ. Calif. Publ. Geol. Sci.. vol. 32, (64 pp.).

Wilson, M., 1989. Igneous Petrogenesis, First edition Springerhttps://doi.org/10.1007/ 978-94-010-9388-0. 